\title{
Implementation of the Fast-JX Photolysis scheme (v6.4) into the UKCA component of the MetUM chemistry-climate model (v7.3)
}

\author{
P. J. Telford ${ }^{1,2}$, N. L. Abraham ${ }^{1,2}$, A. T. Archibald ${ }^{1,2}$, P. Braesicke ${ }^{1,2}$, M. Dalvi ${ }^{3}$, O. Morgenstern ${ }^{4}$, F. M. O'Connor ${ }^{3}$, \\ N. A. D. Richards ${ }^{5}$, and J. A. Pyle ${ }^{1,2}$ \\ ${ }^{1}$ NCAS Climate, University of Cambridge, Cambridge CB2 1EW, UK \\ ${ }^{2}$ Centre for Atmospheric Science, Department of Chemistry, University of Cambridge, Cambridge CB2 1EW, UK \\ ${ }^{3}$ Met Office Hadley Centre, Exeter, UK \\ ${ }^{4}$ National Institute of Water and Atmospheric Research, Lauder, New Zealand \\ ${ }^{5}$ Institute for Climate and Atmospheric Science, School of Earth and Environment, University of Leeds, UK
}

Correspondence to: P. J. Telford (paul.telford@atm.ch.cam.ac.uk)

Received: 3 October 2012 - Published in Geosci. Model Dev. Discuss.: 17 October 2012

Revised: 10 January 2013 - Accepted: 15 January 2013 - Published: 7 February 2013

\begin{abstract}
Atmospheric chemistry is driven by photolytic reactions, making their modelling a crucial component of atmospheric models. We describe the implementation and validation of Fast-JX, a state of the art model of interactive photolysis, into the MetUM chemistry-climate model. This allows for interactive photolysis rates to be calculated in the troposphere and augments the calculation of the rates in the stratosphere by accounting for clouds and aerosols in addition to ozone. In order to demonstrate the effectiveness of this new photolysis scheme we employ new methods of validating the model, including techniques for sampling the model to compare to flight track and satellite data.
\end{abstract}

\section{Introduction}

In the recent past efficient comprehensive photolysis schemes have been developed that are fast enough to be run within global, three dimensional models, allowing a more interactive treatment of photolysis rates in composition modelling (Wild et al., 2000; Tie et al., 2003). These have been implemented into a range of global, three dimensional models (see for instance Liu et al., 2006; Voulgarakis et al., 2009) and have been demonstrated to provide an improved description of atmospheric composition, especially in regions with large variability in optical depths. The optical depth of the atmosphere is composed of several constituents, including the air itself, a phenomenon known as Rayleigh scattering, oxy- gen, ozone, clouds, and aerosols (see, for instance, Wild et al. (2000) for more details) .

The UKCA module is a component of the UK Met Office's Unified Model (MetUM). A number of model configurations have been established and tested; one with stratospheric chemistry (Morgenstern et al., 2009), one with tropospheric chemistry (O'Connor et al., 2009; O'Connor et al., 2013; Telford et al., 2010) and one with the GLOMAPmode aerosol scheme (Mann et al., 2010). There are also whole atmosphere chemistry schemes that have been developed from the tropospheric and stratospheric chemistries (Archibald et al., 2012; Morgenstern et al., 2012). We describe the addition of the Fast-JX photolysis code into the MetUM framework and evaluate it against a range of observations.

Although we make some comparisons in an idealised atmosphere based on the one defined by the CCMVal model intercomparison (Chipperfield et al., 2010), the main evaluation here is carried out using a "nudged" tropospheric model simulation from 2004 through to 2008. The technique of nudging constrains the model to meteorological reanalyses, allowing the model to reproduce the observed weather (Telford et al., 2008). This allows us to make comparisons with an expanded range of data sets, including those from campaigns and from satellites. Although most of our validation is performed on the tropospheric model, as this is where the interactive photolysis is more important because of the effects of clouds, we also include a short section on 
the performance of the stratospheric model by comparing total ozone column and ozone profiles to observations.

\section{Model description}

The UKCA chemistry module is part of the Met Office's Unified Model (MetUM). We employ a version of the model based on the HadGEM3 configuration (Hewitt et al., 2011), but with the following configuration:

- a horizontal resolution of $3.75^{\circ} \times 2.5^{\circ}$ in longitude and latitude.

- 60 hybrid height levels in the vertical, from the surface up to a height of $84 \mathrm{~km}$.

A time series of sea surface temperatures and sea ice coverage are prescribed from the HadISST dataset (Rayner et al., 2003).

\subsection{Nudging}

The technique of nudging is used to reproduce the atmospheric conditions over the period studied. The nudging is applied from 3 to $45 \mathrm{~km}$ with a relaxation timescale of $6 \mathrm{~h}$ (Telford et al., 2008). For the first time we nudge to the ERAInterim reanalysis data (Dee et al., 2011) instead of the ERA40 reanalyses. ERA-Interim are the latest reanalysis products from the ECMWF with the following changes from the ERA40 reanalysis: higher horizontal resolution, 4D-var data assimilation, new humidity analyses, improved model physics, and a different period of coverage (1979-2012 compared to 1957-2002 in ERA-40).

\subsection{Tropospheric chemistry}

The tropospheric version of the model employs a mediumsized chemistry scheme that simulates the $\mathrm{O}_{\mathrm{x}}, \mathrm{HO}_{\mathrm{x}}$ and $\mathrm{NO}_{\mathrm{x}}$ chemical cycles and the oxidation of $\mathrm{CO}$, ethane, propane, and isoprene (Telford et al., 2010). The Mainz isoprene mechanism (Pöschl et al., 2000) is used to parameterise isoprene oxidation. In total the model has 168 chemical reactions and 56 chemical tracers. We also add the additional reaction between $\mathrm{HO}_{2}$ and $\mathrm{NO}$ using the rates and yields of Butkovskaya et al. (2007) and hydrolysis of $\mathrm{N}_{2} \mathrm{O}_{5}$ (Morgenstern et al., 2009). Concentrations of ozone and $\mathrm{NO}_{\mathrm{y}}$ are overwritten above $30 \mathrm{hPa}$. The upper boundary condition for $\mathrm{NO}_{\mathrm{y}}$ are taken from the Cambridge 2-D model (Law and Pyle, 1993a,b). The upper boundary conditions for $\mathrm{O}_{3}$ are taken from the Rosenlof climatology (Dall'Amico et al., 2010), with the model values being overwritten above the upper boundary. Methane is fixed to $1.76 \mathrm{ppm}$ throughout the atmosphere. Dry deposition and wet deposition are parameterised using the approaches of Giannakopoulos et al. (1999).

Seven chemical species (nitrogen oxide (NO), carbon monoxide $(\mathrm{CO})$, formaldehyde $(\mathrm{HCHO})$, ethane, propane, acetaldehyde and acetone $\left.\left(\left(\mathrm{CH}_{3}\right)_{2} \mathrm{CO}\right)\right)$ are emitted in the manner of Zeng and Pyle (2003). Isoprene $\left(\mathrm{C}_{5} \mathrm{H}_{8}\right)$ emissions are included in a similar manner, though with a diurnal cycle as in Young (2007). The emissions are taken from a sum of anthropogenic and natural emissions, with anthropogenic and biomass burning emissions taken from Lamarque et al. (2010) using data for the year 2000. We also lump the emissions of ethene and ethyne with ethane, and propene with propane. Aircraft emissions of NO are taken from Eyers et al. (2004). We also include biogenic emissions of $\mathrm{CO}, \mathrm{Me}_{2} \mathrm{CO}$ and $\mathrm{C}_{5} \mathrm{H}_{8}$ and emissions of $\mathrm{NO}$ from natural soil emissions and lightning. The biogenic emissions are distributed according to Guenther et al. (1995) and total $40 \mathrm{Tg} \mathrm{yr}^{-1}$ of CO from the oceans and $45 \mathrm{Tgyr}^{-1}$ of $\mathrm{CO}, 40 \mathrm{Tgyr}^{-1}$ of $\mathrm{Me}_{2} \mathrm{CO}$ and $570 \mathrm{Tg} \mathrm{yr}^{-1}$ of $\mathrm{C}_{5} \mathrm{H}_{8}$ from the land. We include, on average, $5 \mathrm{Tg} \mathrm{yr}^{-1}$ of $\mathrm{N}$ from lightning emissions, distributed according to the parameterisation of Price and Rind (1994). Finally we include $5.6 \mathrm{Tg} \mathrm{yr}^{-1}$ of $\mathrm{N}$ from natural soil emissions distributed according to the empirical model of Yienger and Levy II (1995). The model uses the aerosol model of Bellouin et al. (2007) using emissions from 2000.

\subsection{Stratospheric chemistry}

The stratospheric version of the model has a comprehensive stratospheric chemistry, including chlorine and bromine chemistry, heterogeneous processes on polar stratospheric clouds (PSCs), and liquid sulphate aerosols as well as a simplified tropospheric chemistry (Morgenstern et al., 2009). More detailed descriptions of the stratospheric version of the chemistry can be found in Morgenstern et al. (2009).

There are a few differences between the stratospheric model used in this study and that in Morgenstern et al. (2009). The base version of the climate model has been updated to HadGEM3 from HadGEM1a. In addition, $\mathrm{N}_{2} \mathrm{O}$ is now transported completely separately from the other odd nitrogen species and the reaction $\mathrm{N}_{2} \mathrm{O}+\mathrm{O}\left({ }^{1} \mathrm{D}\right)$ has been updated with rates from a more recent JPL assessment (Sander et al., 2006).

\subsection{Offline photolysis schemes}

In earlier versions of the model, photolysis rates were determined from rates calculated offline under average conditions, tabulated and interpolated for use online. There were two schemes, one for use in the troposphere, and one for use in the stratosphere. The tropospheric configuration of the chemistry model exclusively used the tropospheric photolysis scheme. The stratospheric configuration of the chemistry model used the tropospheric photolysis scheme below $300 \mathrm{hPa}$, the stratospheric photolysis scheme above $200 \mathrm{hPa}$ with a linear transition between the two schemes from $200 \mathrm{hPa}$ and $300 \mathrm{hPa}$.

The tropospheric photolysis scheme employed the twostream method of Hough (1988) with clouds included as 
a zonally averaged offline distribution (Law et al., 1998). The photolysis rates depended only on latitude, local solar time, month of the year and pressure. The stratospheric scheme was based on the look up table approach of Lary and Pyle (1991), with some updated cross-section measurements (Morgenstern et al., 2009). The rates in the stratospheric scheme responded to changes in the overhead ozone column using a simple scaling.

Apart from a simple scaling to account for changes in stratospheric ozone in the stratospheric scheme, these schemes did not respond to changes in optical depth, relying instead on average conditions for particular latitudes and altitudes. This precluded us from looking at a complete set of feedbacks caused by variations in the optical depth (from e.g. clouds, aerosols) onto atmospheric composition, limiting our ability to simulate the atmosphere. The addition of a more complete interactive photolysis scheme allows us to overcome this hurdle.

\subsection{Fast-J interactive photolysis schemes}

Recently, interactive photolysis schemes have been developed that are fast enough to be incorporated into global models. The original Fast-J scheme was developed for tropospheric photochemistry (Wild et al., 2000). It arranged light from wavelengths between 289 to $850 \mathrm{~nm}$ into seven discrete bins. A further development, Fast-J2, extended the scheme into the stratosphere (Bian and Prather, 2002) by adding 11 wavelength bins from $177-290 \mathrm{~nm}$. To speed up the code, the Rayleigh scattering for the additional wavelengths was treated as pseudo absorption. In the absence of this scattering, Fast-J2 fails to reproduce stratospheric photolysis rates at low solar zenith angles or at dusk, yielding problems in the high latitude winter stratosphere (Morgenstern et al., 2009) and has difficulties in describing the effects of high aerosol loadings. Fast-JX builds on these two schemes, providing the full scattering calculation for all 18 wavelength bins (Neu et al., 2007). It also has several other improvements, most notably a more efficient way of introducing extra levels for very optically dense clouds. It is the implementation of this code $^{1}$ into the MetUM model that we describe.

\section{Technical implementation}

We take the Fast-JX code from the Fast-JX website ${ }^{2}$, hereafter referred to as Prather et al. (2010). Given the optical depth from absorbing and scattering species, this code determines how many photons of each wavelength are absorbed and scattered as light passes through the atmosphere.

This is done using the "plane parallel assumption" which assumes that, for a grid box, the horizontal properties are constant and radiative transfer properties only depend on

\footnotetext{
${ }^{1}$ Version 6.4

${ }^{2}$ http://www.ess.uci.edu/ prather/fastJX.html (version 6.4)
}

the vertical coordinate. Radiative fluxes between horizontally adjacent grid boxes is also neglected. The calculation of the radiative properties thus divides into a series of columns. The path of the radiation is traced through this column, being scattered or absorbed according to the contents of the grid box. The amount of scattering and absorption depends on the optical depth of the different scatterers in the grid box.

The photolysis rates (" $j$ " rates) for each reaction are determined from the wavelength bin-resolved flux in each grid box and the cross section of each species in each wavelength bin. These cross sections are evaluated from experimental measurements of the photolysis rates as described in Sect. 3.2 and, apart from $\mathrm{O}_{3}$, are actually a product of the absorption cross section and quantum yield for a particular reaction. In ozone the total absorption cross section and quantum yields are calculated separately. Because Fast-JX still does not provide photolysis rates for wavelengths below $177 \mathrm{~nm}$, which are important for some reactions in the upper stratosphere and mesosphere we evaluate the cross sections for these wavelengths using the original offline scheme from Lary and Pyle (1991) and add them to the Fast-JX reaction rates. For speed this extra calculation is only performed above $20 \mathrm{~Pa}$, as below this level the flux of these high energy photons is negligible.

\subsection{Calculation of optical depth}

The optical depth $(\tau)$ is determined as the sum of the optical depth of ice water clouds $\left(\tau_{\mathrm{w}}\right)$, liquid water clouds $\left(\tau_{\mathrm{i}}\right)$, aerosols, ozone and oxygen and Rayleigh scattering.

The optical depth of liquid water clouds is calculated using the parameterisation of Slingo (1989),

$\tau_{\mathrm{w}}=\operatorname{LWP}\left(a_{\mathrm{i}}+\frac{b_{\mathrm{i}}}{r_{\mathrm{eff}}}\right)$.

Here LWP is the liquid water path of the cloud, $a_{\mathrm{i}}$ and $b_{\mathrm{i}}$ are parameters and $\mathrm{r}_{\mathrm{eff}}$ is the effective radius of the water droplets. The parameters, which are taken to be $-8.9 \mathrm{~m}^{2} \mathrm{~kg}^{-1}$ and $1.67 \times 10^{3} \mathrm{~m}^{3} \mathrm{~kg}^{-1}$, are updated from Edwards and Slingo (1996). The effective radius is assumed to be $6 \mu \mathrm{m}$ over land and $12 \mu \mathrm{m}$ over water.

The optical depth of ice water clouds is calculated using the non spherical parameterisation of Edwards et al. (2007),

$\tau_{\mathrm{i}}=\operatorname{IWP}\left(c_{\mathrm{i}}+\frac{d_{\mathrm{i}}}{d_{\mathrm{eff}}}+\frac{e_{\mathrm{i}}}{d_{\mathrm{eff}}^{2}}\right)$.

Here IWP is the ice water path of the cloud, $c_{\mathrm{i}}, d_{\mathrm{i}}$ and $e_{\mathrm{i}}$ are parameters updated to account for the different spectral bands and $d_{\text {eff }}$ is the effective diameter of the ice particles. The values of $c_{\mathrm{i}}, d_{\mathrm{i}}$ and $e_{\mathrm{i}}$ are $-2.189 \mathrm{~m}^{2} \mathrm{~kg}^{-1}, 3.311 \times$ $10^{-3} \mathrm{~m} \mathrm{~kg}^{-1}$ and $3.611 \times 10^{-12} \mathrm{~kg}^{-1}$, respectively. The effective diameter is taken to be $100 \mu \mathrm{m}$.

Neu et al. (2007) noted the importance of accounting for the effects of overlapping cloud layers, describing several 
means of doing it. We account for this effect using the simple approach of Briegleb (1992) where the optical depth is modified by the factor $f^{3 / 2}$, where $f$ is the fraction of each grid box area covered by clouds. This has been demonstrated by Feng et al. (2004) to produce a computationally cheap representation of the effects of overlapping cloud layers being used extensively in global models (Liu et al., 2006; Voulgarakis et al., 2009).

The only aerosol accounted for at present is sulphate, which is taken from the models' own fields. The effect of hygroscopic growth on particle size and optical depth is parameterised using the approach of Fitzgerald (1975) as used by Bellouin et al. (2007).

The ozone, oxygen and Rayleigh scattering optical depths are calculated from the molecular columns $\left(\mathrm{mol} \mathrm{cm}^{-2}\right)$ of ozone, oxygen and total air mass, multiplied by the cross sections for $\mathrm{O}_{3}, \mathrm{O}_{2}$ and for Rayleigh scattering. The molecular column for raleigh scattering is calculated from the density in a grid box, the column for $\mathrm{O}_{2}$ is calculated from the density multiplied by the mixing ratio of $\mathrm{O}_{2}$ in the atmosphere, which is assumed to be constant (0.2095). The ozone column is calculated from the density multiplied by the mixing ratio of $\mathrm{O}_{3}$ in each grid cell.

All optical depths are determined at $600 \mathrm{~nm}$ and then scaled for the different wavelength bins. For the purposes of determining the addition of extra levels in the presence of high optical depths, only the cloud optical depth is used.

\subsection{Calculation of cross sections}

The cross sections are based on v6.4 of the file available from the Fast-JX website (Prather et al., 2010). This data set is a combination from the JPL14 assessment (Sander et al., 2003) with the addition of IUPAC data for $\mathrm{NO}_{2}$ and VOC photolysis rates and of other sundry additions such as the acetone photolysis of Blitz et al. (2004) and the infrared photolysis of $\mathrm{HO}_{2} \mathrm{NO}_{2}$ of Jiménez et al. (2005). We have updated these cross sections to include data from JPL15 assessment (Sander et al., 2006), with the most notable changes including updates for $\mathrm{N}_{2} \mathrm{O}_{5}$ and $\mathrm{OClO}$ photolysis. We summarise all reactions described, noting whether they are utilised by the stratospheric or tropospheric chemistry, in Table 4.

\section{Methodology}

To test the performance of the model we carry out a series of tests. The first of these is to investigate how the standalone photolysis code performs under idealised conditions. To do this we employ the scenarios devised for the PHOTOCOMP photolysis study as part of the CCMVal chemistry-climate model intercomparison (Chipperfield et al., 2010).

We then proceed to investigate how the MetUM model with the Fast-JX photolysis included performs. To do this we perform a run with the tropospheric chemistry version of the model, from 2004 to 2008 and compare two different sets of observations, including data from the INTEX campaign and the TES satellite instrument. To enable us to make more direct comparisons we run the model in "nudged mode" (Telford et al., 2008). This constrains the model to meteorological observations, making comparisons with data over our chosen years more meaningful.

The first brief check we make is to ensure that nudging with the ERA-Interim dataset is as successful as nudging with the ERA-40 dataset. We do this by comparing biases, correlations and root mean square differences between the nudged model and analyses as used by Telford et al. (2008). We then proceed to compare photolysis rates with observations from the INTEX-NA campaign, sampling the model at the time and location of the measurements. We make a quantitative assessment of the offline and interactive photolysis schemes by comparing biases, correlations and root mean square differences (RMSD) between the model and the observations.

We then study the effects these changes in photolysis rates have on atmospheric composition, focusing on ozone and carbon monoxide. Our principal comparisons are with observations from the TES satellite instrument, comparing both the distributions of $\mathrm{CO}$ and $\mathrm{O}_{3}$ and their correlation. We sample the model in a similar manner to Rodgers and Connor (2003), taking measurements at the appropriate time and location at the satellite and applying the instrument's averaging kernels to make comparisons more meaningful. To understand the changes in the chemical species distributions we also study the ozone budgets and changes in $\mathrm{OH}$.

Finally, we briefly examine results from a stratospheric simulation, comparing the total ozone column with observations. For this run we do not use nudging in order to allow feedbacks from chemistry to dynamics to influence the model.

\section{Model results}

\subsection{Idealised comparison}

We first check the photolysis rates of $\mathrm{NO}, \mathrm{O}_{2}$ and $\mathrm{O}_{3}{ }^{3}$ under idealised conditions using the three assessed scenarios from the PHOTOCOMP assessment of the CCMVal model intercomparison (see Sect. 6.3.1 in Chipperfield et al., 2010). These employed idealised atmospheric conditions to allow systematic comparisons between the photolysis in different models. The three scenarios used clear sky conditions with a solar zenith angle of $15^{\circ}, 84^{\circ}$ and averaged over a day between $84^{\circ}$ and $96^{\circ}$.

We compare photolysis rates as a function of altitude in a series of idealised atmospheric profiles constructed for a multi-model comparison study. The photolysis rates for

\footnotetext{
${ }^{3}$ This is the total $\mathrm{O}_{3}$ photolysis rate.
} 


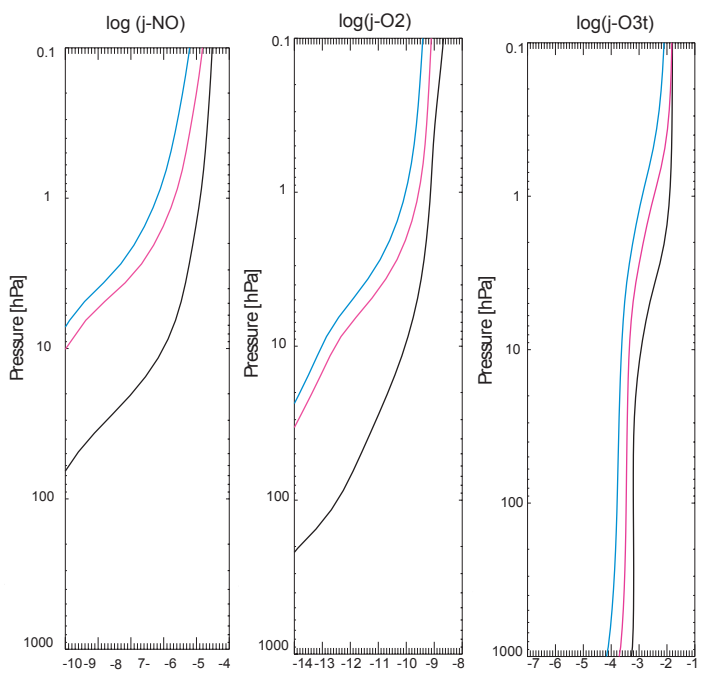

Fig. 1. Photolysis rates for the CCMVal photolysis assessment scenarios for $\mathrm{NO}$ (left), $\mathrm{O}_{2}$ (centre) and $\mathrm{O}_{3}$ (right). The three lines correspond to a solar zenith angle of $15^{\circ}$ (black), $84^{\circ}$ (pink) and averaged over a day between $84^{\circ}$ and $96^{\circ}$ (blue). This figure can be compared to Fig. 6.1 in Chipperfield et al. (2010).

$\mathrm{NO}, \mathrm{O}_{2}$ and $\mathrm{O}_{3}$ are shown in Fig. 1, which can be compared to Fig. 6.1 in Chipperfield et al. (2010).

The $\mathrm{O}_{3}$ photolysis rates look similar to the PHOTOCOMP average, reducing from around $10^{-2} \mathrm{~s}^{-1}$ at $0.1 \mathrm{hPa}$ to between $10^{-4}-10^{-3} \mathrm{~s}^{-1}$ near the surface, depending on the solar zenith angle. Similarly, the $\mathrm{O}_{2}$ photolysis rates look similar to the PHOTOCOMP average, reducing from around $10^{-9} \mathrm{~s}^{-1}$ at $0.1 \mathrm{hPa}$ to below $10^{-14} \mathrm{~s}^{-1}$ between 20 and $200 \mathrm{hPa}$ depending on the solar zenith angle. The NO photolysis rates are the exception, being highly biased throughout the atmosphere. At the top of the atmosphere the photolysis rates are around $10^{-5} \mathrm{~s}^{-1}$ in contrast to the PHOTOCOMP average, which is nearer to $10^{-6} \mathrm{~s}^{-1}$. This is consistent with the models that employ Fast-JX in the PHOTOCOMP study, which see good agreement with the multi-model mean photolysis rates for $\mathrm{O}_{2}$ and $\mathrm{O}_{3}$, but report a high bias in the case of NO. This discrepancy has been linked to factors such as a neglect of NO absorption in the calculation of the optical depth, leading to an overestimate of the modelled cross section. Indeed in the latest versions of Fast-JX the NO photolysis has been scaled by a factor of 0.6 to account for these factors.

Given the general successful performance under idealised conditions, we move on to studying the effects of the photolysis code within the wider chemistry climate model.

\subsection{Validation of nudged tropospheric MetUM run}

After demonstrating that the standalone photolysis scheme works well under idealised conditions we test the performance of the scheme within a MetUM model run.
Table 1. Quantitative assessment of model performance in October 2005 with ERA-Interim nudging using the statistical assessments of Telford et al. (2008) for potential temperature $(\theta)$ and zonal wind $(u)$. This calculates the model mean on four representative model levels and determines the root mean squared error (RMSE) and correlations over time (TC) and space (SC) with respect to the ERAInterim analyses on these same levels.

\begin{tabular}{|c|c|c|c|c|c|}
\hline & Level & Mean and Bias & RMSE & $\mathrm{TC}$ & $\mathrm{SC}$ \\
\hline \multirow{4}{*}{$\theta$} & 6 & $285.3+0.5 \mathrm{~K}$ & $2.7 \mathrm{~K}$ & 0.75 & 0.98 \\
\hline & 16 & $306.8+0.1 \mathrm{~K}$ & $0.5 \mathrm{~K}$ & 0.97 & 1.00 \\
\hline & 29 & $414.9+0.1 \mathrm{~K}$ & $0.6 \mathrm{~K}$ & 0.99 & 1.00 \\
\hline & 35 & $608.5+0.2 \mathrm{~K}$ & $1.0 \mathrm{~K}$ & 0.98 & 1.00 \\
\hline \multirow{4}{*}{$u$} & 6 & $4.19+0.01 \mathrm{~ms}^{-1}$ & $3.37 \mathrm{~m} \mathrm{~s}^{-1}$ & 0.79 & 0.91 \\
\hline & 16 & $7.40-0.01 \mathrm{~ms}^{-1}$ & $1.45 \mathrm{~ms}^{-1}$ & 0.96 & 0.99 \\
\hline & 29 & $13.52-0.13 \mathrm{~ms}^{-1}$ & $1.17 \mathrm{~ms}^{-1}$ & 0.97 & 1.00 \\
\hline & 35 & $16.19-0.22 \mathrm{~ms}^{-1}$ & $1.37 \mathrm{~ms}^{-1}$ & 0.97 & 1.00 \\
\hline
\end{tabular}

\subsubsection{Validation of nudging with ERA-Interim analyses}

As this is the first time we have used ERA-Interim reanalysis data in the nudging we briefly re-evaluate the nudging performance. To do this we use the simple statistical tests of Telford et al. (2008), calculating the bias, correlation and root mean square difference between the nudged model and the ERA-Interim data, which show how similar the nudged model is to the ERA-Interim analyses. These results are shown in Table 1. The performance of the nudging is broadly similar to that when using ERA-40 (compare to Table 1 in Telford et al., 2008), with the most notable difference being the reduction in the RMSE of potential temperature $(\theta)$ in the stratosphere. This could reflect improvements in the data assimilation in the stratosphere (Dee et al., 2011), or just changes in the underlying model. Although the RMSE for potential temperature decreases, a small bias in zonal wind is introduced, so it is not just unalloyed improvement. Even so, from these results, we conclude that the model nudged towards the ERA-Interim analyses can be used as a hindcast of the period 2004 to 2008. This is consistent with the results of Kipling et al. (2013) who show that nudging towards ERA-Interim analyses was able to improve modeled aerosol properties.

\subsubsection{Comparison of cloud optical depth}

The greatest values and variability in the tropospheric optical depth arise from clouds. To demonstrate the model is able to provide a reasonable description of this cloud optical depth we compare our modelled distribution with satellite data. Because of its high temporal resolution, we chose to compare to the ISCCP (International Satellite Cloud Climatology Project) D2 data sets (Rossow et al., 1996; Rossow and Schiffer, 1999), which are constructed from the output 
ISCCP OBSERVATIONS
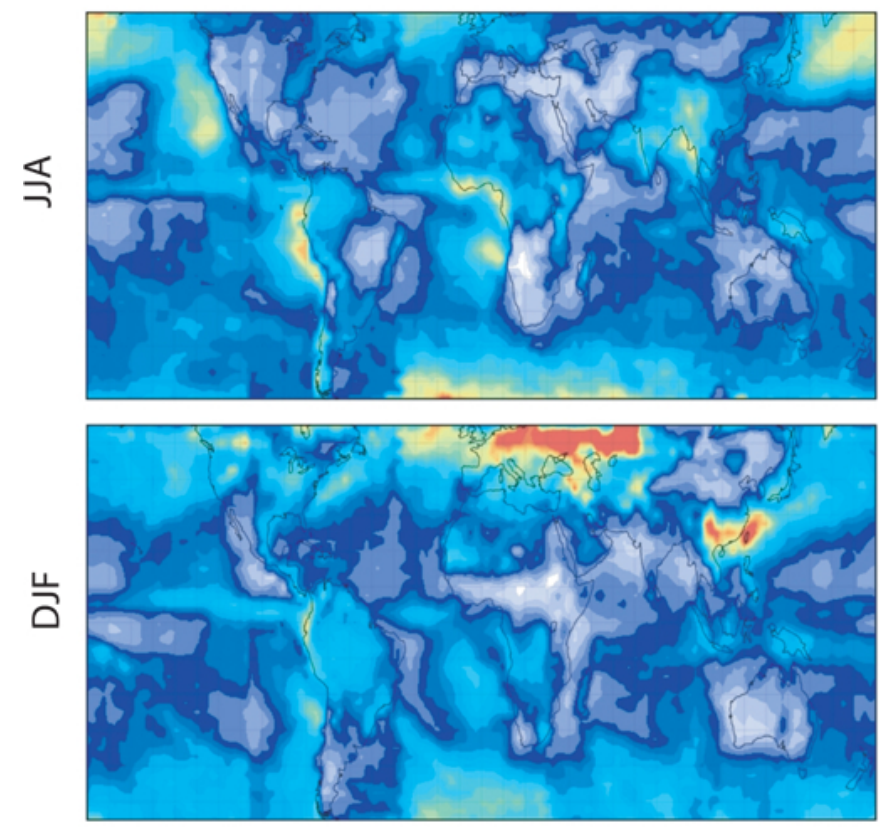

MODELED CLOUD
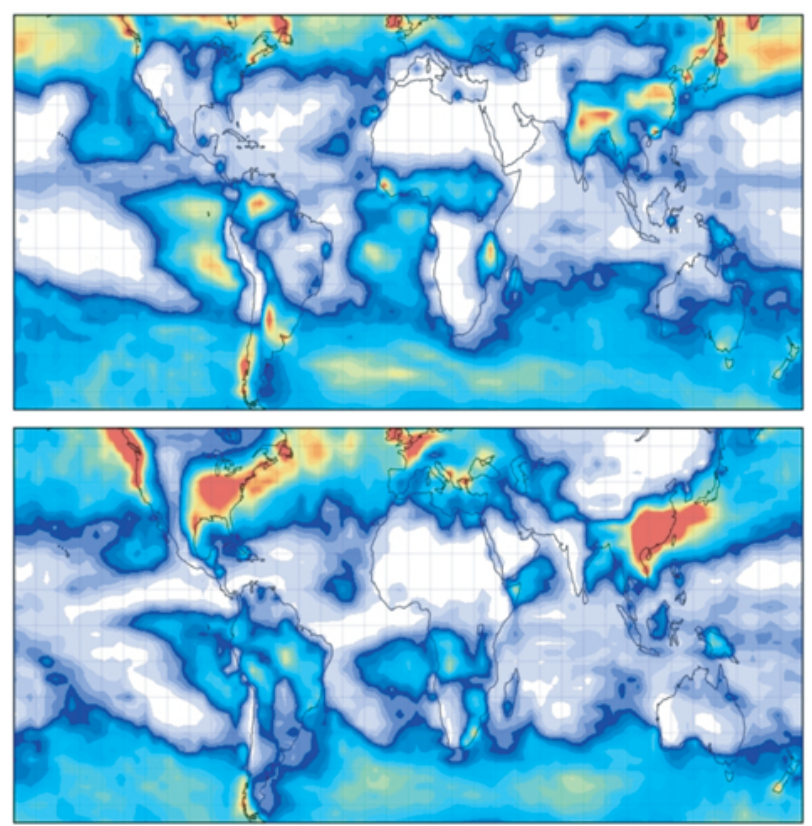

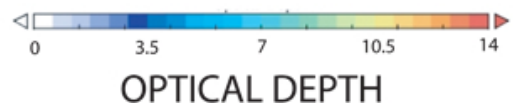

Fig. 2. Average cloud optical depth from ISCCP satellite data (left) and the UM (right). The top row contains a comparison for the Northern Hemisphere summer season and the bottom row for the winter season.

of several NOAA (the American National Oceanic Atmospheric Administration) satellites. The comparisons for December, January and February 2005 and June to August 2005 are shown in Fig. 2.

The model is able to capture many of the features of the observations. For instance the storm tracks in the Northern Atlantic and Pacific oceans are well reproduced, as are the decks of stratus clouds off the coast of Peru. There are some discrepancies between the model and data, for instance the model underestimates the optical depth in the intertropical convergence zone (ITCZ). It also produces too large optical depths over land in the winter, notably China, the Pacific coast of North America and the eastern USA in DJF and Chile in JJA, which may reflect an underestimate of the radii of the cloud particles in these locations at this time. Some of the other differences can be attributed to issues with the data, with errors introduced at high solar zenith angles, contamination from dust, and an underestimate of the amount of optically thick cloud (Marchand et al., 2010). For instance the discrepancy between the model and observations over the Sahara is likely a result of factors such as dust in the measurements rather than a deficiency in clouds in the model. However some of the discrepancies can be attributed to the simplified calculation of cloud optical depth and the limited resolution of the model. From the general good agreement we conclude that the model is able to provide a reasonable description of the cloud optical depth, with the agreement being at least as good as that in other models (see e.g. Voulgarakis et al., 2009).

\subsubsection{Comparison of photolysis rates with INTEX campaign data}

Although the modelled photolysis performs well under an idealised scenario, to more fully evaluate its performance we compare the modelled photolysis rates, with the interactive and offline photolysis schemes, to observational data. The observations we choose to use are from the INTEX-A flight campaign, conducted over North America and the Atlantic in the summer of 2004 (Singh et al., 2006). On these flights the actinic flux was measured in different wavelength regions using spectral radiometers and photolysis rates were obtained by multiplying by cross sections from Sander et al. (2003). This procedure to measure photolysis rates has been reported to be accurate to around 15-20\% (Shetter and Müller, 1999).

The use of the nudged version of the MetUM model allows us to make meaningful comparisons with the campaign data on a measurement by measurement basis. To do this we sample the model at the same time and location as the measurements were made, an approach similar 

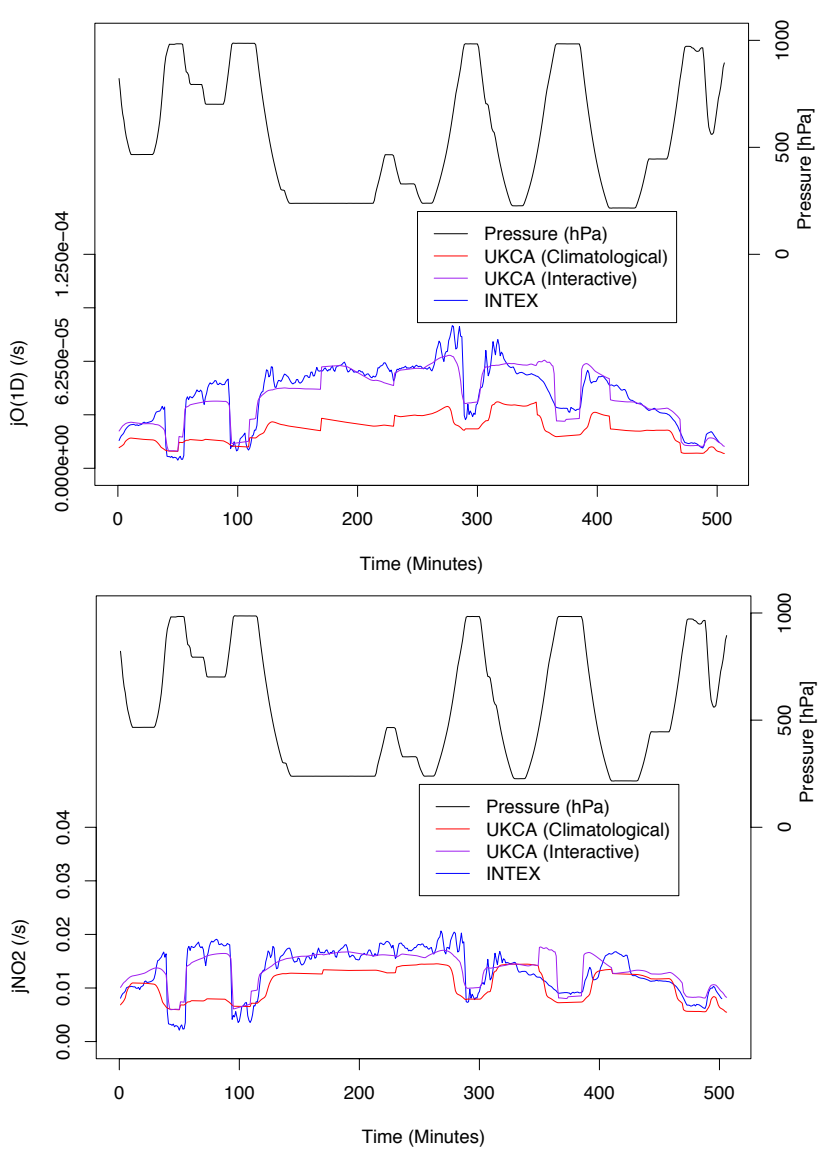

Fig. 3. Comparison of $\mathrm{O}_{3} \rightarrow \mathrm{O}\left({ }^{1} \mathrm{D}\right)$ (top) and $\mathrm{NO}_{2}$ (bottom) photolysis rates during the first flight (1 July 2004) in the INTEX-A campaign between observations and the model with offline and interactive photolysis rates.

to O'Connor et al. (2005) and employed by Kipling et al. (2013), interpolating the model to the pressure and coordinates where the measurements were made. As noted by O'Connor et al. (2005), the relatively low resolution that we use will prevent us from resolving small scale features in the observations. However we expect that we can produce the larger scale features relating to altitude, latitude and time of day. Figure 3 shows the $\mathrm{O}_{3}$ and $\mathrm{NO}_{2}$ photolysis rates from the first flight of the INTEX-A campaign (1 July 2004) and in the MetUM model, with and without interactive photolysis rates.

The $\mathrm{O}_{3}$ photolysis rate is shown to be significantly improved by the use of the interactive photolysis rates, with the low bias removed. The capture of the variability of the photolysis rates is also improved, reflecting that the improved ability of the interactive photolysis rates to $\mathrm{NO}_{2}$ photolysis rate is not as dramatic, though it can be seen that the interactive photolysis reduces a smaller bias and captures the variability better.
Figure 3 only shows one flight from the entire campaign. Although we chose this at random, selecting the first flight in the data, it is possible that the conditions might favour one photolysis scheme in particular. Therefore we calculate the bias, correlation, and root mean square difference (RMSD) between the modelled photolysis rates and the observed rates for all flights (1 July 2004 to 15 August 2004). The biases provide information on average rates. The correlations indicate the ability of the model to capture the variability in the photolysis. The RMSD combines information about average agreement and variability. The biases, correlations and RMSD are given in Table 2 for the two rates shown in Fig. 3, along with selected other rates.

The tabulated results are in accord with Fig. 3, with the interactive photolysis having lower biases and higher correlations with the data than the offline photolysis. For several reactions, including $\mathrm{O}_{3}$ photolysis, the discrepancy between the offline photolysis and the data is considerably larger than the reported experimental uncertainty. For the interactive photolysis there are much smaller differences between the average model and observed values. Some of the reactions where there are differences between the model and the interactive photolysis and data, most notably HONO, are those where there have been updates to the reference cross sections. In the case of HONO, the values (Sander et al., 2006) used in the interactive photolysis now incorporate additional measurements (Kenner and Stuhl, 1986; Stutz et al., 2000). This is relevant as the observed photolysis rates are not measured directly, but are a product of the measured radiation multiplied by cross sections from Sander et al. (2003). So some of the discrepancy can be attributed to an improved understanding of the experimental cross sections. Whilst some of the bias with the offline scheme can be attributed to the failure to update the photolysis rates using more recent measurements and a simple treatment of cloud optical depth, much can be attributed to an overestimation of the stratospheric ozone column in the ozone climatology used to derive the offline photolysis rates.

By inspecting Fig. 3 we also see, as expected, that the global model, with either photolysis scheme, is not designed to describe small-scale variations. However the use of the interactive photolysis, rather than the offline scheme, does produce notable improvements. The correlation between the interactive photolysis and data is always greater than 0.8 and only greater than 0.8 for the photolysis rates of one species, $\mathrm{HCHO}$, with the offline scheme. This can be explained by the fact that the photolysis rates are now sensitive to changes in cloud optical depth.

Although the Fast-JX code is designed to run using 18 wavelength bins, it can be run using a subset of 8 or 12 of these, where the lower wavelength bins are excluded. We repeated the comparison between the model with the default Fast-JX model and with 8 and 12 bins. The largest differences are found in the ozone photolysis rates. The photolysis rates with 8 and 12 bins only differ slightly from each other, but at 
Table 2. Quantitative comparison between photolysis rates from INTEX data and modelled rates with interactive and offline photolysis using all flights (1 July 2004 to 15 August 2004).

\begin{tabular}{|c|c|c|c|c|c|c|}
\hline \multirow[b]{2}{*}{ Reaction } & \multicolumn{3}{|c|}{ Offline } & \multicolumn{3}{|c|}{ Interactive } \\
\hline & $\begin{array}{l}\text { Bias } \\
(\%)\end{array}$ & Correl. & $\begin{array}{c}\text { RMSD } \\
(\%)\end{array}$ & $\begin{array}{r}\text { Bias } \\
(\%)\end{array}$ & Correl. & $\begin{array}{c}\text { RMSD } \\
(\%)\end{array}$ \\
\hline $\mathrm{O}_{3} \rightarrow \mathrm{O}_{2}+\mathrm{O}(1 \mathrm{D})$ & -48 & 0.83 & 55 & 0 & 0.91 & 15 \\
\hline $\mathrm{NO}_{2} \rightarrow \mathrm{NO}+\mathrm{O}(3 \mathrm{P})$ & -20 & 0.65 & 31 & 2 & 0.85 & 18 \\
\hline $\mathrm{CH}_{3} \mathrm{CHO} \rightarrow \mathrm{CH}_{3} \mathrm{OO}+\mathrm{HO}_{2}+\mathrm{CO}$ & 115 & 0.19 & 135 & -13 & 0.85 & 44 \\
\hline $\mathrm{CH}_{3} \mathrm{ONO}_{2} \rightarrow \mathrm{HO}_{2}+\mathrm{HCHO}+\mathrm{NO}_{2}$ & -19 & -0.03 & 46 & -1 & 0.88 & 17 \\
\hline $\mathrm{H}_{2} \mathrm{O}_{2} \rightarrow \mathrm{OH}+\mathrm{OH}$ & -24 & 0.70 & 34 & -2 & 0.88 & 16 \\
\hline $\mathrm{HCHO} \rightarrow \mathrm{HO}_{2}+\mathrm{HO}_{2}+\mathrm{CO}$ & -35 & 0.82 & 41 & 4 & 0.92 & 15 \\
\hline $\mathrm{HCHO} \rightarrow \mathrm{H}_{2}+\mathrm{CO}$ & -31 & 0.81 & 39 & -4 & 0.91 & 16 \\
\hline $\mathrm{HONO} \rightarrow \mathrm{OH}+\mathrm{NO}$ & -21 & 0.66 & 33 & -23 & 0.83 & 30 \\
\hline $\mathrm{HO}_{2} \mathrm{NO}_{2} \rightarrow \mathrm{HO}_{2}+\mathrm{NO}_{2}$ & -22 & 0.77 & 31 & 0 & 0.88 & 15 \\
\hline $\mathrm{PAN} \rightarrow \mathrm{CH}_{3} \mathrm{CO}_{3}+\mathrm{NO}_{2}$ & -87 & 0.47 & 92 & 12 & 0.82 & 23 \\
\hline
\end{tabular}

high altitudes are appreciably lower than the default scheme. The difference can be as large as $7 \%$ with a bias of $1 \%$, averaged over all measurements. The correlation and RMSE are unchanged to two significant figures. Although for studies focussed on the lower troposphere the reduced wavelength bin schemes are acceptable, for studies that examine the upper troposphere and stratosphere the default setting (that of using all 18 wavelength bins) would be required.

\subsubsection{Comparison of ozone and carbon monoxide to TES measurements}

After demonstrating that the photolysis rates look reasonable we investigate their effects on the tracer distributions, comparing model simulations, with the offline and interactive photolysis schemes, and measurements. The large spatial and temporal scales of satellite observations make them ideal to be employed in this capacity. We compare to observations of ozone and carbon monoxide from the TES satellite instrument.

The Tropospheric Emission Spectrometer (TES) is an infrared Fourier transform spectrometer (Beer et al., 2001) onboard NASA's Aura satellite, which was launched in 2004. In this study we utilise $\mathrm{CO}$ and ozone profile observations from the TES Global Survey mode. In this mode profiles have a nadir footprint of $5.3 \times 8.3 \mathrm{~km}$ and are spaced approximately $180 \mathrm{~km}$ apart along the orbital track with a 16 day repeat cycle.

In order to be able to make systematic comparisons between the model and the TES observations, we have developed code that samples the model online at the times and locations of the satellite measurements. This differs slightly from the technique used in previous studies, such as that used by Voulgarakis et al. (2011), who took relatively high frequency global (three hourly) averages and sampled these as close to the time and location of the TES measurements as possible ${ }^{4}$. After interpolating the modelled values of $\mathrm{O}_{3}$ and $\mathrm{CO}$ onto pressure levels used by the TES retrievals, we here apply averaging kernels following the method of Rodgers and Connor (2003), a procedure which is shown to be vital by the study of Aghedo et al. (2011). We bin the $\mathrm{O}_{3}$ and $\mathrm{CO}$ data from the model and the data into $4^{\circ} \times 5^{\circ}$ bins and average from $800-400 \mathrm{hPa}$ before processing using the averaging kernel matrix supplied with the TES observations. This matrix contains information, for each retrieved level, on the contributions to that level of the measured mixing ratio from the different levels in the atmosphere.

First we compare the ozone distributions between the model, with interactive and offline photolysis schemes, and the TES observations ((Nassar et al., 2008), Fig. 4). For consistency with Voulgarakis et al. (2011) we compare for the periods July to August and January to February. With either photolysis scheme, the model captures the main features such as the low ozone values over the western tropical Pacific and the products of biomass burning from southern Africa. The modelled ozone, with either photolysis scheme, is slightly higher ( $9 \%$ averaged over both periods) than the observations. Validation of TES ozone profiles against ozonesondes and LIDAR observations have shown that TES itself has a mean high bias in this altitude region of 5-10\% (Nassar et al., 2008; Richards et al., 2008). This contrasts to the previous version of the model ${ }^{5}$, which had a slight low bias (see Fig. 2 in Voulgarakis et al., 2011). This increase is be-

\footnotetext{
${ }^{4}$ The discrete nature of the model, which has a dynamical time step of $20 \mathrm{~min}$, means that even with this sampling technique we do not take values from the exact same time as the measurements.

${ }^{5}$ The previous version of the model was UMv6.1, similar to that used in Morgenstern et al. (2009), as opposed to the version (UMv7.3) used in the paper which is similar to that used in Hewitt et al. (2011)
} 

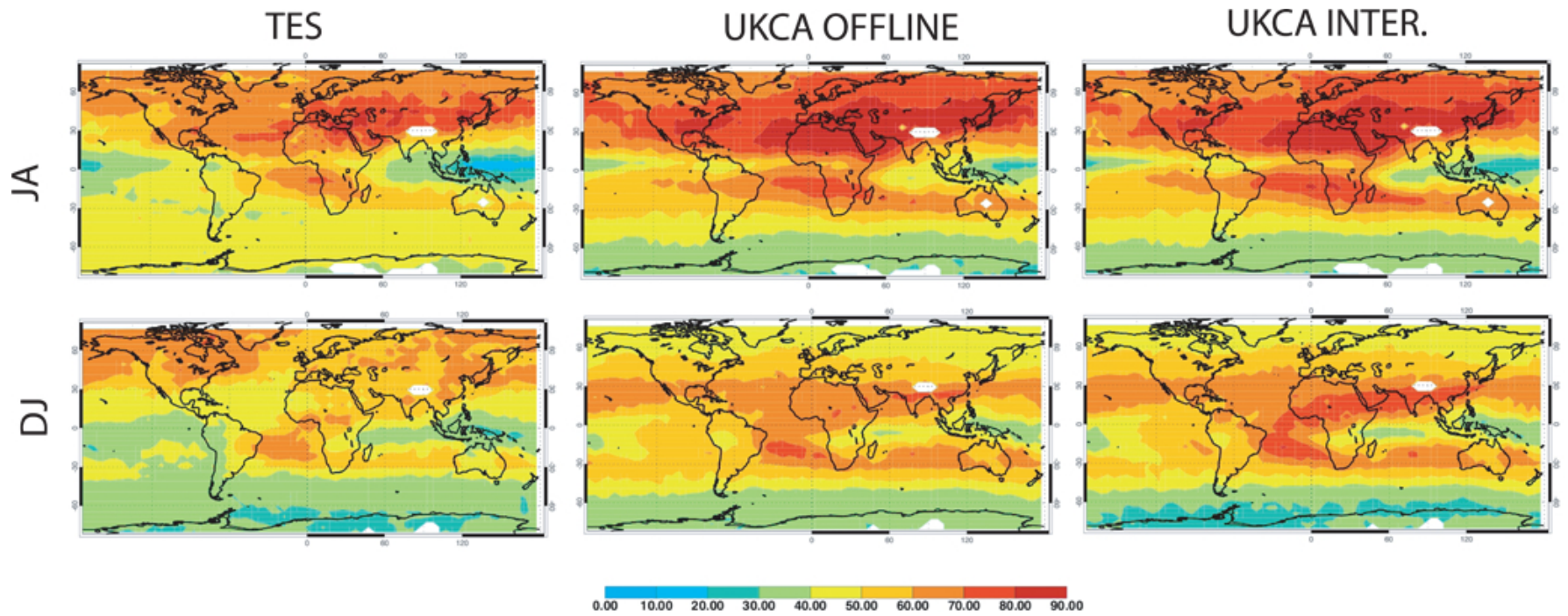

OZONE [ppb]

Fig. 4. Ozone [ppbv] averaged over 800-400 hPa from 2005-2008 July/August (top row) and Dec/Jan (bottom row). Left column: observations from TES. Middle column: model with offline photolysis. Right column: model with interactive photolysis.

lieved to mainly arise from changes in the underlying climate model.

To probe why the changes in photolysis have such a slight impact on the ozone we tabulate the budget of ozone in Table 3 , where we compare the chemical production and loss of ozone in the troposphere ${ }^{6}$, its source from the stratosphere (STE) and its sink to the surface by deposition. We also include the total ozone burden and methane lifetime. As well as the budget from the model with offline and interactive photolysis we include a multi-model average from Stevenson et al. (2006) and results from another version of the MetUM model that employs the interactive photolysis, albeit with simpler tropospheric chemistry (Morgenstern et al., 2012).

We can see that the change in photolysis scheme has a large effect on the chemical production and loss terms, but that the overall, global effect is small, as the changes balance each other. The interactive photolysis has production and loss terms more similar to the multi-model average of Stevenson et al. (2006). The model of Morgenstern et al. (2012) has smaller chemical fluxes, which can be accounted for by its simpler tropospheric chemistry. However, whilst using the same implementation of the interactive photolysis scheme, it produces a relatively low ozone burden and high methane lifetime, indicating that the low methane lifetime seen in the tropospheric chemistry scheme in Table 3 is not an inherent feature of the interactive photolysis scheme, i.e. there are

\footnotetext{
${ }^{6}$ The troposphere is defined as the region below the tropopause, using the combined isentropic-dynamical tropopause of Hoerling et al. (1993)
}

model configurations using the interactive photolysis without a low bias in methane lifetime.

Next we compare the carbon monoxide distributions between the model, with interactive and offline photolysis schemes, and the TES observations (Luo et al., 2007; Lopez et al., 2008) (Fig. 5). Again we compare for the periods July to August and January to February.

The differences between the two versions of the model are now more dramatic. Again both versions capture the broad features with high values of carbon monoxide produced by biomass burning, in particular from Africa, and anthropogenic emissions from Asia. However whilst the model with offline photolysis has only a small bias (2\%), when the interactive photolysis is employed there is a large negative bias $(-24 \%)$. Although there are small positive biases (less than $10 \%$ ) in the tropics and small negative biases in midlatitudes (less than 10\%) in the observations (Luo et al., 2007; Lopez et al., 2008), this model bias is significant. As the emissions are unchanged between the two models, we ascribe these changes to the main sink of $\mathrm{CO}$ and its reaction with the hydroxyl radical, $\mathrm{OH}$. Indeed if we look at the methane lifetime (Table 3), which is dominated by its reaction with $\mathrm{OH}$, we see that this is greatly reduced by switching from the offline to interactive photolysis scheme. We can look directly at the changes in the $\mathrm{OH}$ by plotting the $\mathrm{OH}$ field, weighted as in Lawrence et al. (2001), with the offline and interactive photolysis schemes (Fig. 6).

We first note that the use of the interactive photolysis scheme increases the total $\mathrm{OH}$ burden, which explains the decreased $\mathrm{CO}$ concentrations and $\mathrm{CH}_{4}$ lifetimes. We also note that the amount of $\mathrm{OH}$ is now significantly higher than that reported by Spivakovsky et al. (2000) leading us to believe 
Table 3. Ozone Budget in the troposphere as defined by the tropopause of Hoerling et al. (1993) .

\begin{tabular}{cccccccc}
\hline & $\begin{array}{c}\text { Prod. } \\
\mathrm{Tg} \mathrm{yr}^{-1}\end{array}$ & $\begin{array}{c}\text { Loss } \\
\mathrm{Tg} \mathrm{yr}^{-1}\end{array}$ & $\begin{array}{c}\text { Dry Dep. } \\
\mathrm{Tg} \mathrm{yr}^{-1}\end{array}$ & $\begin{array}{c}\text { Wet Dep. } \\
\mathrm{Tg} \mathrm{yr}^{-1}\end{array}$ & $\begin{array}{c}\text { STE } \\
\mathrm{Tg} \mathrm{gr}^{-1}\end{array}$ & $\begin{array}{c}\text { Burden } \\
\mathrm{Tg}\end{array}$ & $\begin{array}{c}\tau_{\mathrm{CH}_{4}} \\
\mathrm{yr}^{2}\end{array}$ \\
\hline Offline & 4590 & 3460 & 1040 & 120 & 420 & 357 & 9.6 \\
Interactive & 5650 & 4450 & 1010 & 130 & 450 & 351 & 6.7 \\
Stevenson et al. (2006) & $5110 \pm 606$ & $4668 \pm 727$ & $1003 \pm 200$ & $552 \pm 168$ & $344 \pm 39$ & $8.67 \pm 1.32$ \\
Morgenstern et al. (2012) & 3865 & 3451 & 724 & 329 & 296 & 10.5 \\
\hline
\end{tabular}
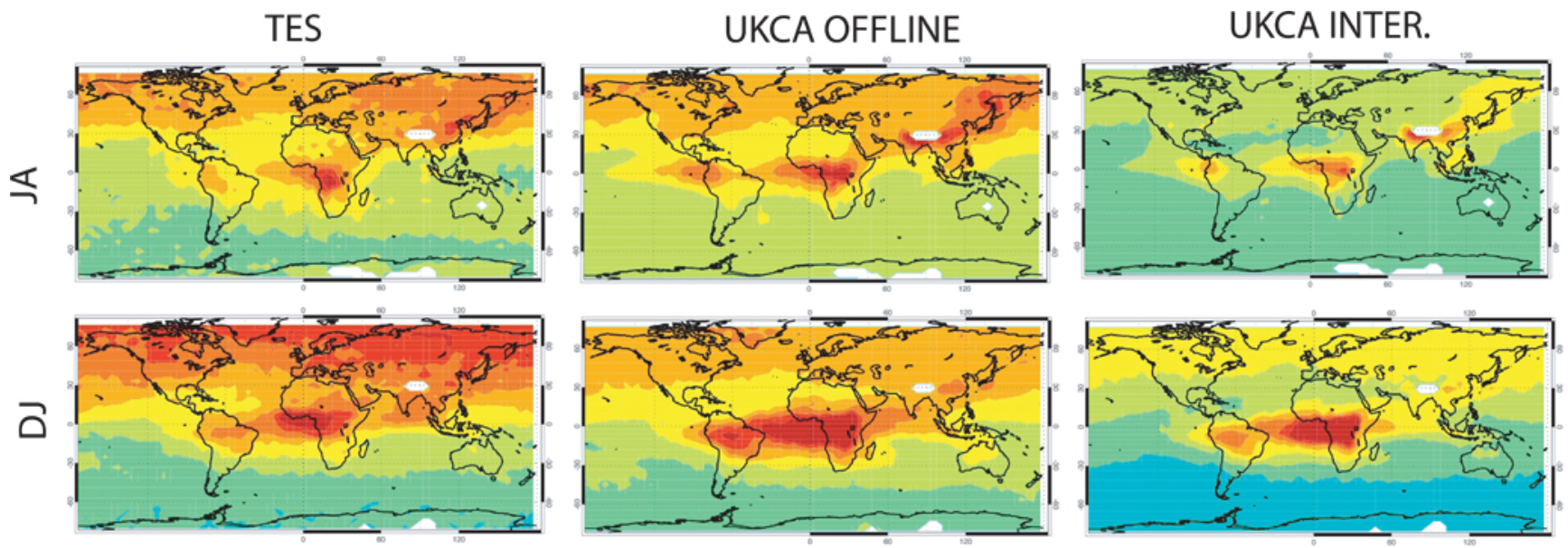

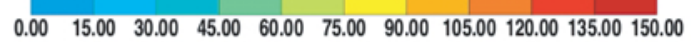

$\mathrm{CO}[\mathrm{ppb}]$

Fig. 5. Carbon Monoxide (ppbv) averaged over $800-400 \mathrm{hPa}$ from 2005-2008 July/August (top row) and December/January (bottom row). Left column: observations from TES. Middle column: model with offline photolysis. Right column: model with interactive photolysis.

that the amount of $\mathrm{OH}$ is excessive. To understand the increase we examined the production and loss terms of $\mathrm{HO}_{\mathrm{x}}$ $\left(\equiv \mathrm{OH}+\mathrm{HO}_{2}\right)$ and found that the increases in $\mathrm{HO}_{\mathrm{x}}$ are dominated by increases in its production via $\mathrm{O}\left({ }^{1} \mathrm{D}\right)+\mathrm{H}_{2} \mathrm{O}$. The water vapour is constant between the two simulations and in a recent study found to compare reasonably well with other models and observations (Russo et al., 2011). Therefore the increase must arise from increased production of $\mathrm{O}\left({ }^{1} \mathrm{D}\right)$, which is produced from the photolysis of ozone. This is greatly increased by using the interactive scheme as can be seen from Fig. 3. However we believe that the increased $j\left(\mathrm{O}\left({ }^{1} \mathrm{D}\right)\right)$ is realistic.

The apparently superior performance of the offline photolysis scheme is a result of two conflicting factors, the high bias in ozone and the low bias in the ozone photolysis rates. Removing one of these factors, although an improvement in itself, thus worsens the performance of some aspects of the model. Indeed Morgenstern et al. (2012) see no such problems with high biases in $\mathrm{OH}$ despite using this implementation of the interactive photolysis scheme, albeit with a considerably different chemistry scheme. Results from a more complete whole atmospheric chemistry (Archibald et al., 2012) also indicate lower ozone concentrations produce lower $\mathrm{OH}$ concentrations, higher $\mathrm{CO}$ concentrations and a longer methane lifetime.

Finally, adopting the approach of Voulgarakis et al. (2011), we compare the $\mathrm{O}_{3}-\mathrm{CO}$ correlations using them to understand the models' performance (Fig. 7). Like previous versions of the model (Voulgarakis et al., 2011) the $\mathrm{O}_{3}-\mathrm{CO}$ correlation is lower in the MetUM model than in the observations. This may reflect the use of climatological biomass burning emissions, which would tend to reduce correlations. On a global scale the two versions of the model perform similarly with "scores" of 0.3 for both photolysis schemes for both periods. The "scores" are obtained by correlating the tracer-tracer correlations in the model and observations. However there are different regions where the two photolysis schemes perform better, with the interactive photolysis producing better agreement near sources of biomass burning (S. America; Central Africa) and the offline scheme performing more strongly in the extra-tropics. This worsening of performance of the interactive photolysis scheme can be linked to the high $\mathrm{OH}$ concentrations attenuating $\mathrm{CO}$ concentrations too rapidly with distance from sources. 
Table 4. Photolysis reactions employed in MetUM Fast-JX and the source of their corresponding absorption cross sections.

\begin{tabular}{|c|c|c|c|}
\hline & Reaction & Notes & Reference \\
\hline 1. & $\mathrm{O}_{2} \rightarrow \mathrm{O}(3 \mathrm{P})+\mathrm{O}(1 \mathrm{D})$ & Cross section 0 in Fast-JX wavelengths. & \\
\hline 2. & $\mathrm{O}_{2} \rightarrow \mathrm{O}(3 \mathrm{P})+\mathrm{O}(3 \mathrm{P})$ & $T$-dependence between 180 and $300 \mathrm{~K}$. & Prather et al. (2010). \\
\hline 3. & $\mathrm{O}_{3} \rightarrow \mathrm{O}_{2}+\mathrm{O}(1 \mathrm{D})$ & $T$-dependence between 180 and $300 \mathrm{~K}$. & Prather et al. (2010). \\
\hline 4. & $\mathrm{O}_{3} \rightarrow \mathrm{O}_{2}+\mathrm{O}(3 \mathrm{P})$ & $T$-dependence between 180 and $300 \mathrm{~K}$. & Prather et al. (2010). \\
\hline 5. & $\mathrm{NO} \rightarrow \mathrm{N}+\mathrm{O}(3 \mathrm{P})$ & & Prather et al. (2010). \\
\hline 6. & $\mathrm{NO}_{2} \rightarrow \mathrm{NO}+\mathrm{O}(3 \mathrm{P})$ & $T$-dependence between 220 and $298 \mathrm{~K}$. & Prather et al. (2010). \\
\hline 7. & $\mathrm{NO}_{3} \rightarrow \mathrm{NO}+\mathrm{O}_{2}$ & $T$-dependence between 190 and $300 \mathrm{~K}$. & Sander et al. (2006). \\
\hline 8. & $\mathrm{NO}_{3} \rightarrow \mathrm{NO}_{2}+\mathrm{O}(3 \mathrm{P})$ & $T$-dependence between 190 and $300 \mathrm{~K}$. & Sander et al. (2006). \\
\hline 9. & $\mathrm{~N}_{2} \mathrm{O}_{5} \rightarrow \mathrm{NO}_{3}+\mathrm{NO}_{2}$ & $T$-dependence between 230 and $300 \mathrm{~K}$. & Sander et al. (2006). \\
\hline 10. & $\mathrm{HONO} \rightarrow \mathrm{OH}+\mathrm{NO}$ & & Sander et al. (2006). \\
\hline 11. & $\mathrm{HONO}_{2} \rightarrow \mathrm{OH}+\mathrm{NO}_{2}$ & $T$-dependence between 200 and $300 \mathrm{~K}$. & Sander et al. (2006). \\
\hline 12. & $\mathrm{HO}_{2} \mathrm{NO}_{2} \rightarrow \mathrm{HO}_{2}+\mathrm{NO}_{2}$ & $\begin{array}{l}T \text {-dependence between } 200 \text { and } 300 \mathrm{~K} \text {. } \\
\text { Includes IR photolysis of Jiménez et al. (2005). }\end{array}$ & Sander et al. (2006). \\
\hline 13. & $\mathrm{~N}_{2} \mathrm{O} \rightarrow \mathrm{N}_{2}+\mathrm{O}(1 \mathrm{D})$ & $T$-dependence between 200 and $300 \mathrm{~K}$. & Prather et al. (2010). \\
\hline 14. & $\mathrm{H}_{2} \mathrm{O} \rightarrow \mathrm{OH}+\mathrm{H}$ & & Sander et al. (2006). \\
\hline 15. & $\mathrm{CH}_{4} \rightarrow \mathrm{CH}_{3} \mathrm{OO}+\mathrm{H}$ & Cross section 0 in Fast-JX wavelengths. & \\
\hline 16. & $\mathrm{CO}_{2} \rightarrow \mathrm{CO}+\mathrm{O}(3 \mathrm{P})$ & $T$-dependence between 195 and $295 \mathrm{~K}$. & Parkinson et al. (2003). \\
\hline 17. & $\mathrm{H}_{2} \mathrm{O}_{2} \rightarrow \mathrm{OH}+\mathrm{OH}$ & $T$-dependence between 200 and $300 \mathrm{~K}$. & Prather et al. (2010). \\
\hline 18. & $\mathrm{HCHO} \rightarrow \mathrm{HO}_{2}+\mathrm{HO}_{2}+\mathrm{CO}$ & $T$-dependence between 223 and $293 \mathrm{~K}$. & Prather et al. (2010). \\
\hline 19. & $\mathrm{HCHO} \rightarrow \mathrm{H}_{2}+\mathrm{CO}$ & $T$-dependence between 223 and $293 \mathrm{~K}$. & Prather et al. (2010). \\
\hline 20. & $\mathrm{CH}_{3} \mathrm{OOH} \rightarrow \mathrm{HO}_{2}+\mathrm{HCHO}+\mathrm{OH}$ & & Sander et al. (2006). \\
\hline 21. & $\mathrm{CH}_{3} \mathrm{CHO} \rightarrow \mathrm{CH}_{3} \mathrm{OO}+\mathrm{HO}_{2}+\mathrm{CO}$ & & Sander et al. (2006). \\
\hline 22. & $\mathrm{CH}_{3} \mathrm{CHO} \rightarrow \mathrm{CH}_{4}+\mathrm{CO}$ & & Sander et al. (2006). \\
\hline 23. & $\mathrm{C}_{2} \mathrm{H}_{5} \mathrm{CHO} \rightarrow \mathrm{C}_{2} \mathrm{H}_{3} 5 \mathrm{OO}+\mathrm{HO}_{2}+\mathrm{CO}$ & & Sander et al. (2006). \\
\hline 24. & $\mathrm{C}_{2} \mathrm{H}_{5} \mathrm{CHO} \rightarrow \mathrm{CH}_{3} \mathrm{OH}+\mathrm{HO}_{2}+\mathrm{OH}$ & & Sander et al. (2006). \\
\hline 25. & $\mathrm{CH}_{3} \mathrm{O}_{3} \mathrm{H} \rightarrow \mathrm{CH}_{3} \mathrm{OO}+\mathrm{OH}$ & & Sander et al. (2006). \\
\hline 26. & $\left(\mathrm{CH}_{3}\right)_{2} \mathrm{CO} \rightarrow \mathrm{CH}_{3} \mathrm{CO} 3+\mathrm{CH}_{3} \mathrm{OO}$ & Using scheme of Blitz et al. (2004). & Prather et al. (2010). \\
\hline 27. & $\mathrm{n}-\mathrm{PrOOH} \rightarrow \mathrm{C}_{2} \mathrm{H}_{5} \mathrm{CHO}+\mathrm{HO}_{2}+\mathrm{OH}$ & Use cross sections from reaction 20. & \\
\hline 28. & $\mathrm{i}-\mathrm{PrOOH} \rightarrow\left(\mathrm{CH}_{3}\right)_{2} \mathrm{CO}+\mathrm{HO}_{2}+\mathrm{OH}$ & Use cross sections from reaction 20. & \\
\hline 29. & $\mathrm{CH}_{3} \mathrm{COCH}_{2} \mathrm{OOH} \rightarrow \mathrm{CH}_{3} \mathrm{CO}_{3}+\mathrm{HCHO}+\mathrm{OH}$ & Use cross sections from reaction 20 & \\
\hline 30. & $\mathrm{HACET} \rightarrow \mathrm{CH}_{3} \mathrm{CO}_{3}+\mathrm{HCHO}+\mathrm{HO}_{2}$ & $\begin{array}{l}\text { Lumped species of } \mathrm{C} 3 \text { carbonyls, including hyd- } \\
\text { roxyacetone. Use hydroxyacetone cross sections. }\end{array}$ & Sander et al. (2006). \\
\hline 31. & $\mathrm{MGLY} \rightarrow \mathrm{CH}_{3} \mathrm{CO}_{3}+\mathrm{CO}+\mathrm{HO}_{2}$ & $\begin{array}{l}\text { Lumped species of } \mathrm{C} 3 \text { aldehydes, including } \\
\text { methyl glyoxal. Use methylglyoxal cross sections. }\end{array}$ & IUPAC datasheet P6 ${ }^{\mathrm{a}}$ \\
\hline 32. & $\mathrm{MACR} \rightarrow \mathrm{CH}_{3} \mathrm{CO}_{3}+\mathrm{HCHO}+\mathrm{CO}+\mathrm{HO}_{2}$ & $\begin{array}{l}\text { Lumped species of C4 carbonyls, including meth- } \\
\text { acrolein. Use methacrolein cross sections. }\end{array}$ & Prather et al. (2010). \\
\hline 33. & $\begin{array}{l}\text { MACROOH } \rightarrow 0.5 \mathrm{HACET}+0.5 \mathrm{CO} \\
+0.5 \mathrm{MGLY}+0.5 \mathrm{HCHO}+\mathrm{OH}+\mathrm{HO}_{2}\end{array}$ & Use cross sections from reaction 20 & \\
\hline 34. & $\mathrm{iSOOH} \rightarrow \mathrm{MACR}+\mathrm{HO}_{2}+\mathrm{HCHO}+\mathrm{OH}$ & Use cross sections from reaction 20. & \\
\hline 35. & $\mathrm{CH}_{3} \mathrm{ONO}_{2} \rightarrow \mathrm{HO}_{2}+\mathrm{HCHO}+\mathrm{NO}_{2}$ & $T$-dependence between 240 and $300 \mathrm{~K}$. & Prather et al. (2010). \\
\hline 36. & $\mathrm{PAN} \rightarrow \mathrm{CH}_{3} \mathrm{CO}_{3}+\mathrm{NO}_{2}$ & $T$-dependence between 250 and $300 \mathrm{~K}$. & Prather et al. (2010). \\
\hline 37. & $\mathrm{PPAN} \rightarrow \mathrm{C}_{2} \mathrm{H}_{5} \mathrm{CO}_{3}+\mathrm{NO}_{2}$ & Use cross sections from reaction 36. & \\
\hline 38. & $\mathrm{MPAN} \rightarrow \mathrm{MACRO}_{2}+\mathrm{NO}_{2}$ & Use cross sections from reaction 36. & \\
\hline 39. & $\mathrm{NALD} \rightarrow \mathrm{HCHO}+\mathrm{CO}+\mathrm{NO}_{2}+\mathrm{CO}_{2}$ & Use cross sections from reaction 21. & \\
\hline 40. & $\mathrm{ISON} \rightarrow \mathrm{NO}_{2}+\mathrm{MACR}+\mathrm{HCHO}+\mathrm{NO}_{2}$ & $\begin{array}{l}\text { Lumped species. Use } i-\mathrm{C}_{3} \mathrm{H}_{7} \mathrm{ONO}_{2} \\
T \text {-dependence between } 230 \text { and } 360 \mathrm{~K} \text {. }\end{array}$ & IUPAC datasheet $\mathrm{P} 17^{\mathrm{b}}$ \\
\hline 41. & $\mathrm{CH}_{3} \mathrm{Br} \rightarrow \mathrm{Br}+\mathrm{H}$ & $T$-dependence between 196 and $296 \mathrm{~K}$. & Prather et al. (2010). \\
\hline 42. & $\mathrm{BrCl} \rightarrow \mathrm{Br}+\mathrm{Cl}$ & $T$-dependence between 190 and $300 \mathrm{~K}$. & Sander et al. (2006). \\
\hline 43. & $\mathrm{BrO} \rightarrow \mathrm{Br}+\mathrm{O}(3 \mathrm{P})$ & & Sander et al. (2006). \\
\hline 44. & $\mathrm{HOBr} \rightarrow \mathrm{Br}+\mathrm{OH}$ & & Prather et al. (2010). \\
\hline 45. & $\mathrm{BrNO}_{3} \rightarrow \mathrm{Br}+\mathrm{NO}_{3}$ & & Sander et al. (2006). \\
\hline 46. & $\mathrm{BrNO}_{3} \rightarrow \mathrm{BrO}+\mathrm{NO}_{2}$ & & Sander et al. (2006). \\
\hline 47. & $\mathrm{CFCl}_{3} \rightarrow \mathrm{Cl}+\mathrm{Cl}+\mathrm{Cl}$ & & Prather et al. (2010). \\
\hline 48. & $\mathrm{CF}_{2} \mathrm{Cl}_{2} \rightarrow \mathrm{Cl}+\mathrm{Cl}$ & & Prather et al. (2010). \\
\hline 49. & $\mathrm{HCl} \rightarrow \mathrm{H}+\mathrm{Cl}$ & & Sander et al. (2006). \\
\hline 50. & $\mathrm{HOCl} \rightarrow \mathrm{Cl}+\mathrm{OH}$ & & Prather et al. (2010). \\
\hline 51. & $\mathrm{OClO} \rightarrow \mathrm{ClO}+\mathrm{O}(3 \mathrm{P})$ & & Sander et al. (2006). \\
\hline 52. & $\mathrm{Cl}_{2} \mathrm{O}_{2} \rightarrow \mathrm{Cl}+\mathrm{Cl}+\mathrm{O}_{2}$ & & Sander et al. (2006). \\
\hline 53. & $\mathrm{ClNO}_{3} \rightarrow \mathrm{Cl}+\mathrm{NO}_{3}$ & & Prather et al. (2010). \\
\hline 54. & $\mathrm{ClNO}_{3} \rightarrow \mathrm{ClO}+\mathrm{NO}_{2}$ & & Prather et al. (2010). \\
\hline
\end{tabular}

${ }^{a}$ http://www.iupac-kinetic.ch.cam.ac.uk/datasheets/pdf/P6_CH3COCHO+hv.pdf

${ }^{\mathrm{b}} \mathrm{http} / / /$ www.iupac-kinetic.ch.cam.ac.uk/datasheets/pdf/P17_i-C3H7ONO2+hv.pdf 

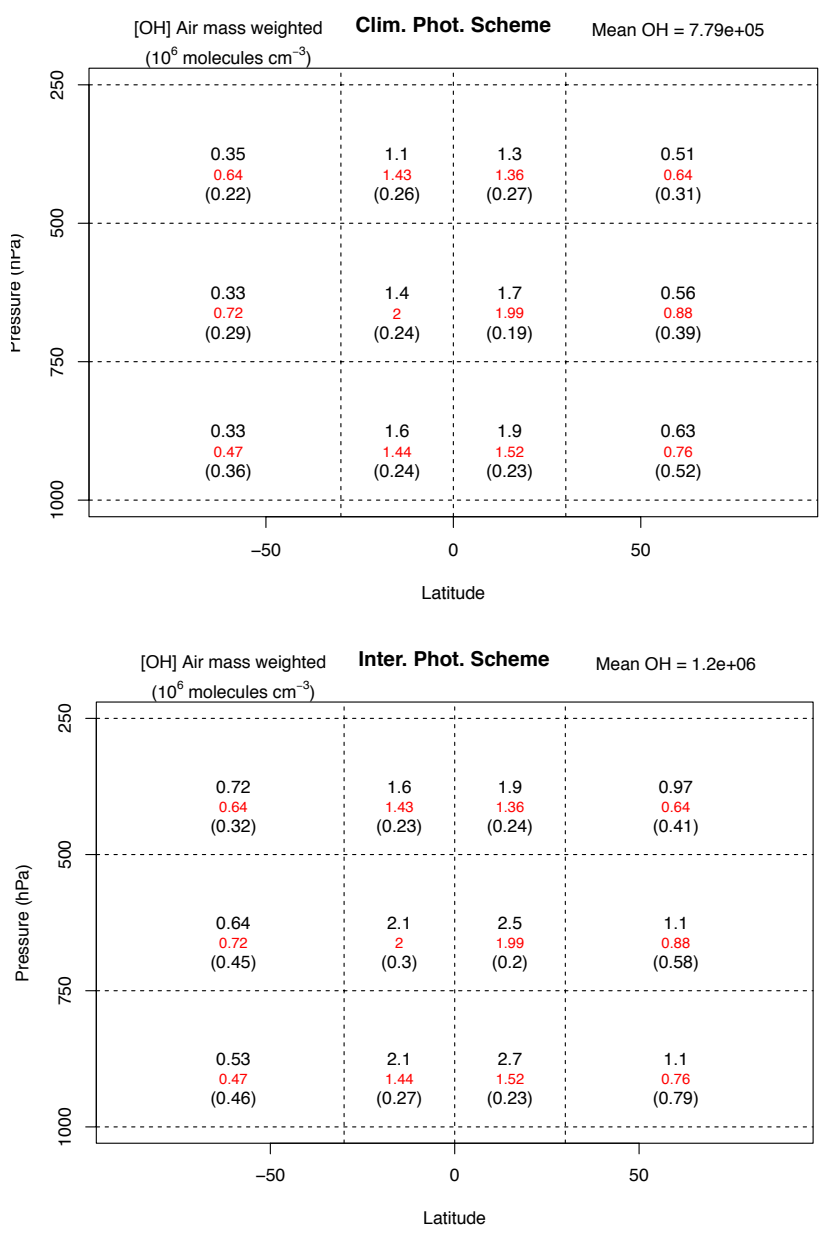

Fig. 6. $\mathrm{OH}$ distribution, weighted as in (Lawrence et al., 2001), as a function of height and latitude. The black numbers are the model values, the red numbers are from the Spivakovsky et al. (2000) climatology (obtained from Lamarque et al., 2012) and the numbers in brackets the standard deviation of the grid cell values used to obtain the average in the model. Top plot with offline photolysis and bottom plot with interactive photolysis.

\subsubsection{Conclusions with regards to tropospheric run}

We have evaluated the performance of the Fast-JX photolysis scheme in the tropospheric version of the MetUM model using a nudged run between 2004 and 2008. After briefly checking that nudging of the ERA-Interim analyses is successful, and that the modelled cloud optical depths were realistic, we proceeded to demonstrate improvements to the modelled photolysis rates using data comparisons from the INTEX-NA campaign. These results showed that the online photolysis model provides a significantly better description of the observed rates. We then investigated the effects that these improved photolysis rates have on the modelled chemical fields, comparing the changes to observations from the TES satellite instrument. The improved photolysis rates, whilst producing some improvements to the chemical fields, produced a high bias in the global burden of $\mathrm{OH}$, which itself affected $\mathrm{CO}$ concentrations and the $\mathrm{CH}_{4}$ lifetime. This was a result of the more realistic photolysis rates increasing the sensitivity of the model to high biases in ozone, the effects of which were masked in the offline photolysis scheme by too small ozone photolysis rates.

\subsection{Stratospheric chemistry}

In addition to testing the model in the troposphere, a further simple validation was performed in the stratosphere. In order to test the feedback from chemical changes onto the dynamics we ran the model unconstrained by nudging. The run we perform is similar to that used in Morgenstern et al. (2009), which itself follows the definition of the REF-B0 experiment of the CCMVal model intercomparison (Eyring et al., 2010). This uses forcings that represent perpetual 2000 conditions, although, as we are able to initialise the chemical fields from those in Morgenstern et al. (2009) we only perform a $10 \mathrm{yr}$ run, discarding the first five years as "spin-up".

In Fig. 8 we examine the average annual cycle of the total ozone column. The values from the model are compared to a combination of data from a variety of sources including TOMS, SBUV, GOME and OMI, for the year 2000 (Bodeker et al., 2005). The model captures most of the features including the latitudinal gradient and timing and magnitude of the Northern Hemisphere spring maximum.

The previous version of the chemistry scheme had some discrepancies with observations around the tropopause, including high biases in temperature and ozone (Morgenstern et al., 2009). To assess how the updated model performs we compare ozone profiles with those from the SHADOZ network (Thompson et al., 2003a,b). We show results from one representative site, Fiji, in Fig. 9 displaying monthly mean ozone profiles as a function of pressure. The model is able to capture the seasonal cycle well, though it does still slightly overestimate UTLS ozone. Tropospheric ozone is slightly low, as should be expected, as this version of the model does not attempt to fully simulate tropospheric emissions and chemistry.

\section{Discussion}

Whilst we have demonstrated that the photolysis rates are improved by the use of the interactive photolysis scheme and that the stratospheric version of the model performs well with it, there are still obvious issues with the tropospheric model. We have demonstrated that these arise from high biases in the ozone concentrations which, without the large low bias in photolysis rates seen in the offline scheme, now produce a high bias in $\mathrm{OH}$. The interactive photolysis scheme does not cause the high bias in ozone, as can be seen from the reduction in the $\mathrm{O}_{3}$ burden in Table 3. In addition, the high bias 
TES
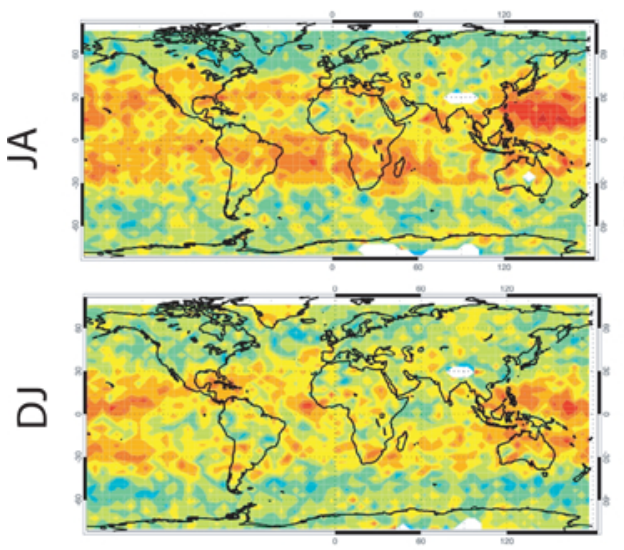

UKCA OFFLINE
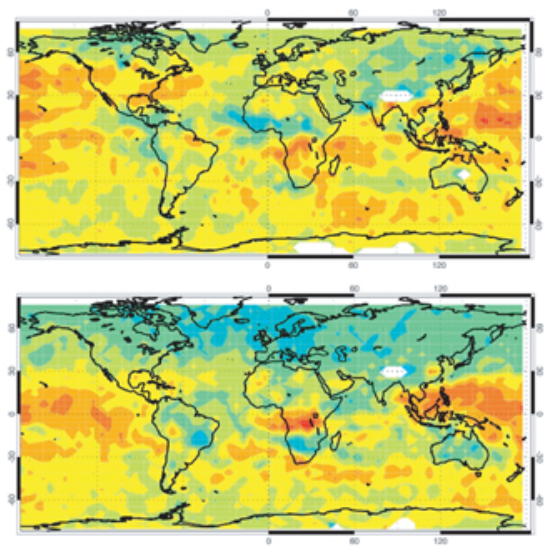

UKCA INTER.
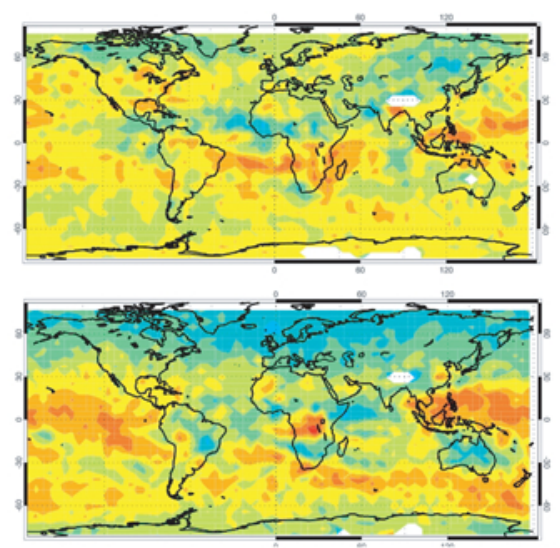

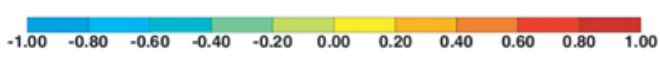

Correlation

Fig. 7. Correlation between "free tropospheric" (800-400 hPa) Ozone and Carbon Monoxide from 2005-2008 July/August (top row) and December/January (bottom row). Left column: observations from TES. Middle column: model with offline photolysis. Right column: model with interactive photolysis.

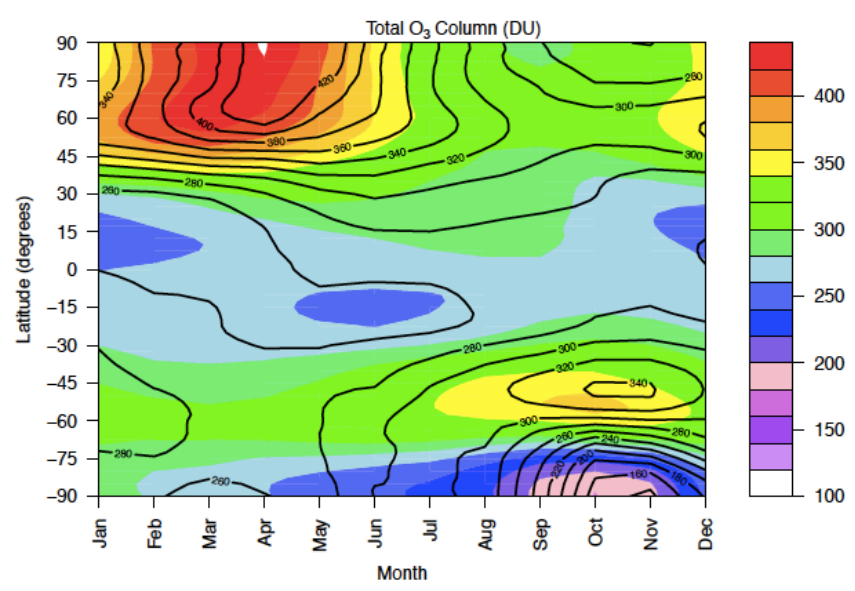

Fig. 8. Comparison between assimilated total ozone column data (Bodeker et al., 2005) (lines) and the stratospheric chemistry model (filled coloured contours).

can be seen with both photolysis schemes when compared to the TES satellite instrument data in Fig. 4.

We have reduced the $\mathrm{O}_{3}$ high bias by various measures, including the replacement of the original upper boundary condition for $\mathrm{NO}_{\mathrm{y}}$ as used by O'Connor et al. (2009) with one from the Cambridge-2D model, adding the additional reaction between $\mathrm{HO}_{2}$ and $\mathrm{NO}$ using the rates and yields of Butkovskaya et al. (2007) and adding the hydrolysis of $\mathrm{N}_{2} \mathrm{O}_{5}$ (Morgenstern et al., 2009). Whilst these reduced the biases in ozone they did not eliminate them. Further work is being carried out at present to try and understand the sources of these biases, but they cannot obscure the improved descrip- tion of observed photolysis rates by the interactive photolysis scheme as opposed to the offline scheme.

Even with the removal of the high biases in ozone there are still ways of expanding the capability of the interactive photolysis scheme. One obvious omission is the limited use of aerosols in the model. This will change when the GLOMAPmode scheme (Mann et al., 2010) is coupled to the photolysis. Although on a global scale aerosols are less important than clouds for the optical depth calculation, there are localised regions where this coupling will be useful. A further improvement, of greater importance for the stratosphere, will be the use of a variable solar constant, a driver of some of the variability in stratospheric ozone. Whilst our simple approach of accounting for overlapping cloud layers seems to work at present, increasing vertical resolution may require more sophisticated techniques to be employed (Neu et al., 2007). The new methods of sampling the model, expanding the data sets it can be validated against, will also be useful in assessing other aspects of the model performance.

\section{Conclusions}

We describe the implementation of the Fast-JX interactive photolysis scheme in the UK Met Office Unified Model. The interactive photolysis scheme is shown to improve the modelled photolysis rates from the previous, offline scheme in comparison to observations and other models. The effect on atmospheric composition is less clear cut, with the interactive photolysis scheme producing too much $\mathrm{OH}$. However this is believed to be a result of a previous cancellation of errors being removed, and not as a result of any inherent problem with 

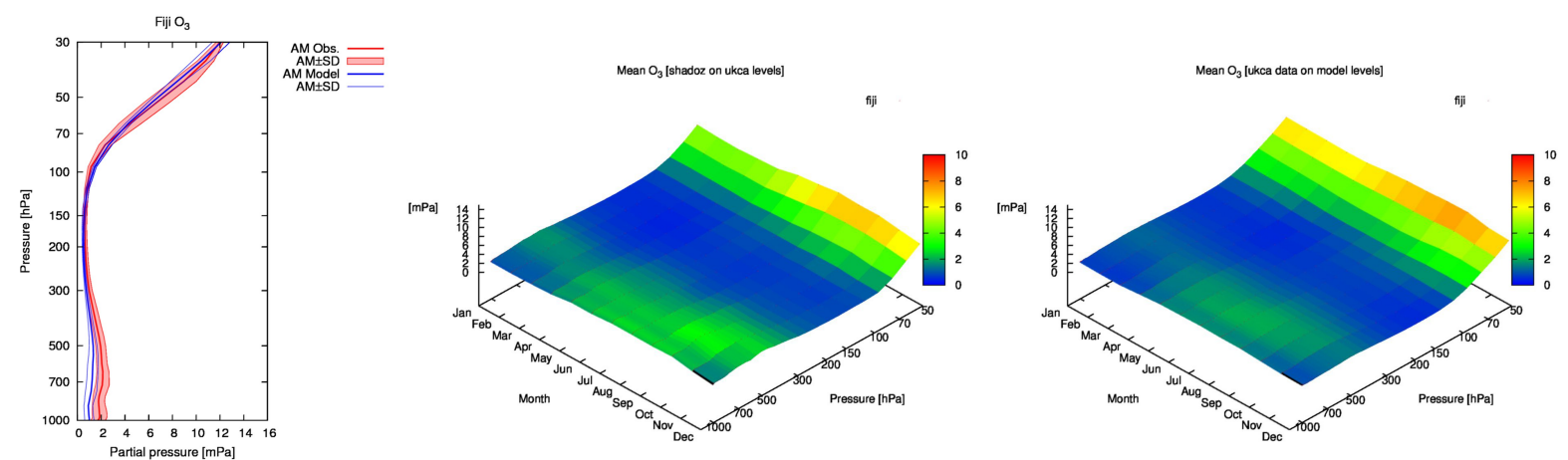

Fig. 9. Comparison of monthly mean $\mathrm{O}_{3}$ profiles between the stratospheric version of the chemistry model and sondes from the SHADOZ network over an example site, in this case Fiji $\left(18^{\circ} \mathrm{S}, 178^{\circ} \mathrm{E}\right)$. The left-hand plot shows annual mean profiles in the model and in the observations. The right-hand plots resolve the variation over the year in observations (left) and the model (right).

the interactive photolysis scheme. As well as being a more realistic manner of modelling, the photolysis the interactive scheme will permit more detailed studies of the interactions between the atmosphere and its constituents.

Acknowledgements. We acknowledge NCAS and NCEO for their funding of this work. MD and FMOC were supported by the Joint DECC/Defra Met Office Hadley Centre Climate Programme (GA01101).

We thank Michael Prather for the provision of the Fast-JX code and Oliver Wild and Apostolos Voulgarakis for insights into its operation. We thank Martyn Chipperfield for his help in comparing the PHOTOCOMP model intercomparison. We thank Glenn Carver and Nick Savage for discussions about the flight track sampling code. We thank Maria Russo for discussions about water vapour and clouds. We acknowledge James Keeble for his work in assisting understanding of the updated stratospheric chemistry.

Biogenic emissions were obtained from the GEIA centre http://www.geiacenter.org/inventories/present.html. The INTEX-A data was obtained from the NASA-LARC website http://www-air.larc.nasa.giv/missions/intexna/intexna.htm. The ISCCP D2 data/images were obtained from the International Satellite Cloud Climatology Project web site http://isccp.giss.nasa.gov maintained by the ISCCP research group at the NASA Goddard Institute for Space Studies, New York, NY on March, 2010 (Rossow and Schiffer, 1999). We would like to thank Greg Bodeker of Bodeker Scientific for providing the combined total column ozone database (http://www.bodekerscientific.com/data/total-column-ozone). We thank the NASA Langley Research Center Atmospheric Science Data Center for the TES data.

Edited by: A. Stenke

\section{References}

Aghedo, A. M., Bowman, K. W., Shindell, D. T., and Faluvegi, G.: The impact of orbital sampling, monthly averaging and vertical resolution on climate chemistry model evaluation with satellite observations, Atmos. Chem. Phys., 11, 6493-6514, doi:10.5194/acp-11-6493-2011, 2011.

Archibald, A. T., Abraham, N. L., Braesicke, P., Dalvi, M., Johnson, C., Keeble, J. M., O’Connor, F. M., Squire, O. J., Telford, P. J., and Pyle, J. A.: Evaluation of the UM-UKCA model configuration for Chemistry of the Stratosphere and Troposphere (CheST), Geosci. Model Dev., in preparation, 2012.

Beer, R., Glavic, T., and Rider, M.: Tropospheric emission spectrometer for the Earth observing System's Aura Satellite, Appl. Optics, 40, 2356-2367, 2001.

Bellouin, N., Boucher, O., Haywood, J., Johnson, C., Jones, A., Rae, J., and Woodward, S.: Improved representation of aerosols for HadGEM2, Tech. rep., Met Office Hadley Centre, 2007.

Bian, H. and Prather, M.: Fast-J2: accurate simulation of stratopheric photolysis in global chemical models, J. Atmos. Chem., 41, 281-296, 2002.

Blitz, M., Heard, D., and Pilling, M.: Pressure and temperaturedependent quantum yields for the photodissociation of acetone between 279 and $327.5 \mathrm{~nm}$, Geophys. Res. Lett., 31, L06111, doi:10.1029/2003GL018793, 2004.

Bodeker, G. E., Shiona, H., and Eskes, H.: Indicators of Antarctic ozone depletion, Atmos. Chem. Phys., 5, 2603-2615, doi:10.5194/acp-5-2603-2005, 2005.

Briegleb, P.: Delta-eddington approximation for solar radiation in the ncar community climate models, J. Geophys. Res., 97, 76037612, 1992.

Butkovskaya, N. I., Kukui, A., and Le Bras, G.: $\mathrm{HNO}_{3}$ forming channel of the $\mathrm{HO}_{2}+\mathrm{NO}$ reaction as a function of pressure and temperature in the ranges of 72-600 Torr and 223-323 K, J. Phys. Chem. A, 111, 9047-9053, 2007.

Chipperfield, M., Kinnison, D., Bekki, S., Bian, H., Brühl, C., Canty, T., Cionni, I., Dhomse, S., Froidevaux, L., Fuller, R., Müller, R., Prather, M., Salawitch, R., Santee, M., Tian, W., and Tilmes, S.: SPARC CCMVal Report on the Evaluation of Chemistry-Climate Models, Stratospheric Chemistry, chapter 6, 191-252, SPARC, http://homepages.see.leeds.ac.uk/ lecmc/ ccmvalj/, 2010.

Dall'Amico, M., Gray, L., Rosenlof, K., Scaife, A., Shine, K., and Stott, P.: Stratospheric temperature trends: impact of ozone variability and the QBO, Clim. Dynam., 34, 381-398, doi:10.1007/s00382-009-0604-x, 2010. 
Dee, D., Uppala, S., Simmons, A., Berrisford, P., Poli, P., Kobayashi, S., Andrae, U., Balmaseda, M. A., Balsamo, G., Bauer, P., Bechtold, P., Beljaars, A. C. M., van de Berg, L., Bidlot, J., Bormann, N., Delsol, C., Dragani, R., Fuentes, M., Geer, A. J., Haimberger, L., Healy, S. B., Hersbach, H., Hólm, E. V., Isaksen, L., Kållberg, P., Köhler, M., Matricardi, M., McNally, A. P., Monge-Sanz, B. M., Morcrette, J.-J., Park, B.-K., Peubey, C., de Rosnay, P., Tavolato, C., Thépaut, J.-N., and Vitart, F.: The ERA-Interim reanaysis: configurationa and performance of the data analysis system, Q. J. Roy. Meteor. Soc., 137, 553-597, doi:10.1002/qj.828, 2011.

Edwards, J. and Slingo, A.: Studies with a flexible new radiation code. I: Choosing a configuration for a large-scale model, Q. J. Roy. Meteor. Soc., 122, 689-719, 1996.

Edwards, J. M., Havemann, S., Thelen, J.-C., and Baran, A.: A new parameterisation for the radiative properties of ice crystals, comparison of existing schemes and impact in a GCM, Atmos. Res., 83, 19-35, doi:10.1016/j.atmosres.2006.03.002, 2007.

Eyers, C., Addleton, D., Atkinson, K., Broomhead, M., Christou, R., Elliff, T., Falk, R., Gee, I., Lee, D., Marizy, C., Michot, S., Middel, J., Newton, P., Norman, P., Plohr, M., Raper, D., and Stanciou, N.: AERO2K global aviation emissions inventories for 2002 and 2025, Tech. Rep. 04/01113, Qinetiq, http://aero-net.info/fileadmin/aeronet_files/links/documents/ AERO2K_Global_Aviation_Emissions_Inventories_for_2002_ and_2025.pdf, 2004.

Eyring, V., Shepherd, T., and Waugh, D.: SPARC Report on the Evaluation of Chemistry-Climate Models, Tech. rep., SPARC Report No. 5, WCRP-132, WMO/TD-N0. 1526, http://www. atmosp.physics.utoronto.ca/SPARC/ccmval_final/index.php, 2010.

Feng, Y., Penner, J. E., Sillman, S., and Liu, X.: Effects of cloud overlap in photochemical models, J. Geophys. Res., 109, D04310, doi:10.1029/2003JD004040, 2004.

Fitzgerald, J.: Approximation formulas for the equilibrium size of an aerosol particle as a function of its dry size and composition and the ambient relative humidity, J. Appl. Meteorol., 14, 1044-1049, doi:10.1175/15200450(1975)014<1044:AFFTES>2.0.CO;2, 1975.

Giannakopoulos, C., Chipperfield, M., Law, K., and Pyle, J.: Validation and intercomparison of wet and dry deposition schemes using $\mathrm{Pb}-210$ in a global three-dimensional off-line chemical transport model, J. Geophys. Res., 104, 23761-23784, 1999.

Guenther, A., Hewitt, C. N., Erickson, D., Fall, R., Geron, C., Graedel, T., Harley, P., Klinger, L., Lerdau, M., McKay, W. A., Pierce, T., Scoles, B., Steinbrecher, R., Tallaamraju, R., Taylor, J., and Zimmerman, P.: A global model of natural volatile organic compound emissions, J. Geophys. Res., 100, 8873-8892, 1995.

Hewitt, H. T., Copsey, D., Culverwell, I. D., Harris, C. M., Hill, R. S. R., Keen, A. B., McLaren, A. J., and Hunke, E. C.: Design and implementation of the infrastructure of HadGEM3: the next-generation Met Office climate modelling system, Geosci. Model Dev., 4, 223-253, doi:10.5194/gmd-4-223-2011, 2011.

Hoerling, M., Schaack, T., and Lenzen, A.: A global analysis of stratospheric-tropospheric exchange during northern winter, Mon. Weather Rev., 121, 162-172, 1993.

Hough, A. M.: The calculation of photolysis rates for use in global modelling studies, Tech. rep., UK Atomic Energy Authority, Har- well, Oxon., UK, 1988.

Jiménez, E., Gierczak, T., Stark, H., Burkholder, J. B., and Ravishankara, A. R.: Quantum yields of $\mathrm{OH}, \mathrm{HO}_{2}$ and $\mathrm{NO}_{3}$ in the UV photolysis of $\mathrm{HO}_{2} \mathrm{NO}_{2}$, Phys. Chem. Chem. Phys., 7, 342-348, 2005.

Kenner, R. D., Rohrer. F., and Stuhl, F.: Hydroxyl (A) production in the 193-nm photolysis of nitrous acid, J. Phys. Chem., 90, 26352639, 1986.

Kipling, Z., Stier, P., Schwarz, J. P., Perring, A. E., Spackman, J. R., Mann, G. W., Johnson, C. E., and Telford, P. J.: Constraints on aerosol processes in climate models from vertically-resolved aircraft observations of black carbon, Atmos. Chem. Phys. Discuss., 13, 437-473, doi:10.5194/acpd-13-437-2013, 2013.

Lamarque, J.-F., Bond, T. C., Eyring, V., Granier, C., Heil, A., Klimont, Z., Lee, D., Liousse, C., Mieville, A., Owen, B. Schultz, M. G., Shindell, D., Smith, S. J., Stehfest, E., Van Aardenne, J., Cooper, O. R., Kainuma, M., Mahowald, N., McConnell, J. R., Naik, V., Riahi, K., and van Vuuren, D. P.: Historical (1850-2000) gridded anthropogenic and biomass burning emissions of reactive gases and aerosols: methodology and application, Atmos. Chem. Phys., 10, 7017-7039, doi:10.5194/acp10-7017-2010, 2010.

Lamarque, J.-F., Emmons, L. K., Hess, P. G., Kinnison, D. E., Tilmes, S., Vitt, F., Heald, C. L., Holland, E. A., Lauritzen, P. H., Neu, J., Orlando, J. J., Rasch, P. J., and Tyndall, G. K.: CAMchem: description and evaluation of interactive atmospheric chemistry in the Community Earth System Model, Geosci. Model Dev., 5, 369-411, doi:10.5194/gmd-5-369-2012, 2012.

Lary, D. and Pyle, J.: Diffuse-radiation, twilight, and photochemistry, J. Atmos. Chem., 13, 393-406, 1991.

Law, K. and Pyle, J.: Modeling trace gas budgets in the troposphere 1. ozone and odd nitrogen, J. Geophys. Res., 98, 18377-18400, 1993a.

Law, K. and Pyle, J.: Modeling trace gas budgets in the troposphere 2. $\mathrm{CH}_{4}$ and CO, J. Geophys. Res., 98, 18401-18412, 1993 b.

Law, K., Plantevin, P., Shallcross, D., Rogers, H., Pyle, J., Grouhel, C., Thouret, V., and Marenco, A.: Evaluation of modeled $\mathrm{O}_{3}$ using Measurement of Ozone by Airbus In-Service Aircraft (MOZAIC) data, J. Geophys. Res., 103, 25721-25737, 1998.

Lawrence, M. G., Jöckel, P., and von Kuhlmann, R.: What does the global mean $\mathrm{OH}$ concentration tell us?, Atmos. Chem. Phys., 1, 37-49, doi:10.5194/acp-1-37-2001, 2001.

Liu, H., Crawford, J., Pierce, R., Norris, P., Platnick, S., Chen, G., Logan, J., Yantosca, R., Evans, M., Kittaka, C., Feng, Y., and Tie, X.: Radiative eddect of clouds on tropspheric chemistry in a global three-dimensional chemical transport model, J. Geophys. Res., 111, D20303, doi:10.1029/2005JD006403, 2006.

Lopez, J. P., Luo, M., Christensen, L. E., Loewenstein, M., Jost, H., Webster, C. R., and Osterman, G.: TES carbon monoxide validation during two AVE campaigns using the Argus and ALIAS instruments on NASA's WB-57F, J. Geophys. Res., 113, D16847, doi:10.1029/2007JD008811, 2008.

Luo, M., Rinsland, C., Fisher, B., Sachse, G., Diskin, G., Logan, J., Worden, H., Kulawik, S., Osterman, G., Eldering, A., Herman, R., and Shephard, M.: TES carbon monoxide validation with DACOM aircraft measurements during INTEX-B, J. Geophys. Res., 112, D24848, doi:10.1029/2007JD008803, 2007. 
Mann, G. W., Carslaw, K. S., Spracklen, D. V., Ridley, D. A., Manktelow, P. T., Chipperfield, M. P., Pickering, S. J., and Johnson, C. E.: Description and evaluation of GLOMAP-mode: a modal global aerosol microphysics model for the UKCA composition-climate model, Geosci. Model Dev., 3, 519-551, doi:10.5194/gmd-3-519-2010, 2010.

Marchand, R., Ackerman, T., Smyth, M., and Rossow, W. B.: A review of cloud top height and optical depth histograms from MISR, ISCCP, and MODIS, J. Geophys. Res., 115, D16206, doi:10.1029/2009JD013422, 2010.

Morgenstern, O., Braesicke, P., O’Connor, F. M., Bushell, A. C., Johnson, C. E., Osprey, S. M., and Pyle, J. A.: Evaluation of the new UKCA climate-composition model - Part 1: The stratosphere, Geosci. Model Dev., 2, 43-57, doi:10.5194/gmd-2-432009, 2009.

Morgenstern, O., Zeng, G., Abraham, N., Telford, P., Braesicke, P., Pyle, J., Hardiman, S. C., O'Connor, F. M., and Johnson, C. E.: Impacts of climate change, ozone recovery, and increasing methane on the tropospheric oxodising capacity, J. Geophys. Res., doi:10.1029/2012JD018382, in press, 2012.

Nassar, R., Logan, J. A., Worden, H. M., Megretskaia, I. A., Bowman, K. W., Osterman, G. B., Thompson, A. M., Tarasick, D. W., Austin, S., Claude, H., Manvendra, K., Dubey, W., Hocking, K., Johnson, B. J., Joseph, E., Merrill, J., Morris, G. A., Newchurch, M., Oltmans, S. J., Posny, F., Schmidlin, F. J., Vömel, H., Whiteman, D. N., and Witte, J. C.: Validation of Tropospheric Emission Spectrometer (TES) nadir ozone profiles using ozonesonde measurements, J. Geophys. Res., 113, D15S17, 13 pp., doi:10.1029/2007JD008819, 2008.

Neu, J., Prather, M., and Penner, J.: Global atmospheric chemistry: integrating over fractional cloud cover, J. Geophys. Res., 112, D11306, 12 pp., doi:10.1029/2006JD008007, 2007.

O'Connor, F., Carver, G., Savage, N., Pyle, J. A., Methven, J., Arnold, S. R., Dewey, K., and Kent, J.: Comparison and visualisation of high resolution transport modelling with aircraft measurements, Atmos. Sci. Lett., 6, 164-170, doi:10.1002/asl.111, 2005.

O'Connor, F., Johnson, C., Morgenstern, O., and Collins, W. J.: Interactions between tropospheric chemistry and climate model temperature and humidity biases, Geophys. Res. Lett, 36, L16801, doi:10.1029/2009GL039152, 2009.

O’Connor, F. M., Johnson, C. E., Morgenstern, O., Abraham, N. L., Braesicke, P., Dalvi, M., Folberth, G. A., Sanderson, M. G., Telford, P. J., Young, P. J., Zeng, G., Collins, W. J., and Pyle, J. A.: Evaluation of the new UKCA climate-composition model, Part II. The Troposphere, Geosci. Model Dev. Discuss., in review, 2013.

Parkinson, W., Rufus, J., and Yoshino, K.: Absolute absorption cross section measurements of $\mathrm{CO}_{2}$ in the wavelength region 163-200 nm and the temperature dependence, Chem. Phys., 290, 251-256, 2003.

Pöschl, U., von Kuhlmann, R., Poisson, N., and Crutzen, P.: Development and intercomparison of condensed isoprene oxidation mechanisms for global atmospheric modelling, J. Atmos. Chem., 37, 29-52, 2000.

Price, C. and Rind, D.: Modelling global lightning distributions in a general circulation model, Mon. Weather Rev., 122, 19301939, 1994.
Rayner, A., Rayner, N., Parker, D., Horton, E., Folland, C., Alexander, L., Rowell, D., Kent, E., and Kaplan, A.: Global analyses of sea surface temperature, sea ice, and night marine air temperature since the late nineteenth century, J. Geophys. Res., 108, 4407, 29 pp., doi:10.1029/2002JD002670, 2003.

Richards, N. A. D., Osterman, G. B., Browell, E. V., Hair, J. W., Avery, M., and Li, Q.: Validation of Tropospheric Emission Spectrometer ozone profiles with aircraft observations during the intercontinental chemical transport experiment-B, J. Geophys. Res.-Atmos., 113, D16S29, doi:10.1029/2007jd008815, 2008.

Rodgers, C. D. and Connor, B. J.: Intercomparison of remote sounding instruments, J. Geophys. Res.-Atmos., 108, 4116, doi:10.1029/2002jd002299, 2003.

Rossow, W., Walker, A., Beuschel, D., and Roiter, M.: International Satellite Cloud Climatology Project (ISCCP) Documentation of New Cloud Datasets, Tech. rep., World Meteorological Organization, http://isccp.giss.nasa.gov/pub/documents/d-doc.pdf, 1996.

Rossow, W. B. and Schiffer, R. A.: Advances in understanding clouds from ISCCP, B. Am. Meteorol. Soc., 80, 2261-2287, 1999.

Russo, M. R., Marécal, V., Hoyle, C. R., Arteta, J., Chemel, C., Chipperfield, M. P., Dessens, O., Feng, W., Hosking, J. S., Telford, P. J., Wild, O., Yang, X., and Pyle, J. A.: Representation of tropical deep convection in atmospheric models - Part 1: Meteorology and comparison with satellite observations, Atmos. Chem. Phys., 11, 2765-2786, doi:10.5194/acp-11-27652011, 2011.

Sander, S., Friedl, R., Golden, D., Kurylo, M. J., Huie, R., Orkin, V., Moortgat, G., Ravishankra, A., Kolb, C., Molina, M., and Finlayson-Pitts, B.: Chemical Kinetics and Photochemical Data for Use in Atmospheric Studies Evaluation Number 14, Tech. rep., JPL, http://jpldataeval.jpl.nasa.gov/pdf/JPL_02-25_ rev02.pdf, 2003.

Sander, S., Friedl, R., Golden, D. M., Kurylo, M., Moortgat, G., Keller-Rudek, H., Wine, P., Ravishankra, A. R., Kolb, C., Molina, M., Finlayson, B., Huie, R., and Orkin, V.: Chemical Kinetics and Photochemical Data for Use in Atmospheric Studies Evaluation Number 15, Tech. rep., NASA JPL, http://jpldataeval. jpl.nasa.gov/pdf/JPL_15_AllInOne.pdf, 2006.

Shetter, R. E. and Müller, M.: Photolysis frequency measurements using actinic flux spectroradiometry during the PEM-Tropics mission: Instrumentation description and some result, J. Geophys. Res., 104, 5647-5661, 1999.

Singh, H. B., Crawford, J. H., Jacob, D. J., and Russell, P. B.: Overview of the summer 2004 Intercontinental Chemical Transport Experiment-North America (INTEX-A), J. Geophys. Res., 111, D24S01, doi:10.1029/2006JD007905, 2006.

Slingo, A.: A GCM parameterization for the shortwave radiative properties of water clouds, J. Atmos. Sci., 46, 1419-1427, 1989.

Spivakovsky, C., Logan, J., Montzka, S., Balkanski, Y., ForemanFowler, M., Jones, D., Horowitz, L., Fusco, A., Brenninkmeijer, C., Prather, M., Wofsy, S., and McElroy, M.: Threedimensional climatological distribution of tropospheric OH: update and evaluation, J. Geophys. Res., 105, 8931-8980, 2000.

Stevenson, D., Dentener, F., Schultz, M., Ellingsen, K., van Noije, T., Wild, O., Zeng, G., Amann, M., Atherton, C., Bell, N., Bergmann, D., Bey, I., Butler, T., Cofala, J., Collins, W., Derwent, R., Doherty, R., Drevet, J., Eskes, H., Fiore, A., Gauss, M., 
Hauglustaine, D., Horowitz, L., Isaksen, I., Krol, M., Lamarque, J.-F., Lawrence, M., Montanaro, V., ller, J.-F. M., Pitari, G., Prather, M., Pyle, J., Rast, S., Rodriguez, J., Sanderson, M., Savage, N., Shindell, D., Strahan, S., Sudo, K., and Szopa, S.: Multimodel ensemble simulations of present-day and near-future tropospheric ozone, J. Geophys. Res., 111, D08301, 23 pp., doi:10.1029/2005JD006338, 2006.

Stutz, J., Kim, E. S., Platt, U., Bruno, P., Perrino, C., and Febo, A.: UV-visible absorption cross sections of nitrous acid, J. Geophys. Res., 105, 14585-14592, 2000.

Telford, P. J., Braesicke, P., Morgenstern, O., and Pyle, J. A.: Technical Note: Description and assessment of a nudged version of the new dynamics Unified Model, Atmos. Chem. Phys., 8, 17011712, doi:10.5194/acp-8-1701-2008, 2008.

Telford, P. J., Lathière, J., Abraham, N. L., Archibald, A. T., Braesicke, P., Johnson, C. E., Morgenstern, O., O’Connor, F. M., Pike, R. C., Wild, O., Young, P. J., Beerling, D. J., Hewitt, C. N., and Pyle, J.: Effects of climate-induced changes in isoprene emissions after the eruption of Mount Pinatubo, Atmos. Chem. Phys., 10, 7117-7125, doi:10.5194/acp-10-7117-2010, 2010.

Thompson, A., Witte, J., McPeters, R., Oltmans, S., Schmidlin, F., Logan, J., M.Fujiwara, Kirchhoff, V., Posny, F., Coetzee, G., Hoegger, B., Kawakami, S., Ogawa, T., Johnson, B., Vömel, H., and Labow, G.: Southern Hemisphere Additional Ozonesondes (SHADOZ) 1998-2000 tropical ozone climatology 1. Comparison with Total Ozone Mapping Spectrometer (TOMS) and ground-based measurements, J. Geophys. Res., 108, 8238, doi:10.1029/2001JD000967, 2003a.

Thompson, A., Witte, J., Oltmans, S., Schmidlin, F., Logan, J., Fujiwara, M., Kirchhoff, V., Posny, F., Coetzee, G., Hoegger, B., Kawakami, S., Ogawa, T., Fortuin, J., and Kelder, H.: Southern Hemisphere Additional Ozonesondes (SHADOZ) 19982000 tropical ozone climatology 2. Tropospheric variability and the zonal wave-one, J. Geophys. Res., 108, D28241, doi:10.1029/2002JD002241, 2003b.
Tie, X. X., Madronich, S., Walters, S., Rasch, P., and Collins, W.: Effect of clouds on photolysis and oxidants in the troposphere, J. Geophys. Res., 108, D204642, doi:10.1029/2003JD003659, 2003.

Voulgarakis, A., Savage, N. H., Wild, O., Carver, G. D., Clemitshaw, K. C., and Pyle, J. A.: Upgrading photolysis in the pTOMCAT CTM: model evaluation and assessment of the role of clouds, Geosci. Model Dev., 2, 59-72, doi:10.5194/gmd-2-592009, 2009.

Voulgarakis, A., Telford, P. J., Aghedo, A. M., Braesicke, P., Faluvegi, G., Abraham, N. L., Bowman, K. W., Pyle, J. A., and Shindell, D. T.: Global multi-year $\mathrm{O}_{3}-\mathrm{CO}$ correlation patterns from models and TES satellite observations, Atmos. Chem. Phys., 11, 5819-5838, doi:10.5194/acp-11-5819-2011, 2011.

Wild, O., Zhu, X., and Prather, M.: Fast-J: accurate simulation of in- and below-cloud photolysis in tropospheric chemical models, J. Atmos. Chem., 37, 245-282, doi:10.1023/A:1006415919030, 2000.

Yienger, J. and Levy II, H.: Empirical model of global soil biogenic $\mathrm{NO}_{\mathrm{x}}$ emissions, J. Geophys. Res., 100, 11477-11464, 1995.

Young, P.: The influence of Biogenic Emissions on Atmospheric Chemistry: a Model Study for Present and Future Atmospheres, $\mathrm{PhD}$ thesis, University of Cambridge, http://ulmss-newton.lib. cam.ac.uk/vwebv/holdingsInfo?bibId=30191, 2007.

Zeng, G. and Pyle, J. A.: Changes in tropospheric ozone between 2000 and 2100 modeled in a chemistry-climate model, Geophys. Res. Lett., 30, 1392, 4 pp., doi:10.1029/2002GL016708, 2003. 